\title{
Diachroneity of the Clearwater West and Clearwater East impact structures indicated by the (U-Th)/He dating method
}

\author{
M.B. Biren ${ }^{1}$, M.C. van Soest ${ }^{1}$, J-A.Wartho ${ }^{1,2}$, K.V. Hodges ${ }^{1}$, and J.G. Spray ${ }^{3}$.
}

${ }^{1}$ Group 18 Laboratories, School of Earth and Space Exploration, Arizona State University, Tempe, AZ 85287, USA. Contact: marc.biren@asu.edu.

${ }^{2}$ GEOMAR Helmholtz Centre for Ocean Research, Wischhofstr. 1-3, D-24148 Kiel, Germany.

${ }^{3}$ Planetary and Space Science Centre, University of New Brunswick, 2 Bailey Drive, Fredericton, New Brunswick E3B 5A3, Canada.

\section{Abstract}

The (U-Th)/He method has been applied to constrain the formation ages of the Clearwater West and East impact structures of Quebec, Canada. Zircons were separated from impact melt samples derived from a surface exposure at Clearwater West (32 km diameter), and from a drill core at Clearwater East (26 km diameter). The (U-Th)/He results yield ages of $280 \pm$ $27 \mathrm{Ma}(2 \sigma, \mathrm{n}=7)$ for Clearwater West, and $450 \pm 56 \mathrm{Ma}(2 \sigma, \mathrm{n}=8)$ for Clearwater East. Our $(\mathrm{U}-\mathrm{Th}) / \mathrm{He}$ age for Clearwater West concurs with those of previous Rb-Sr (266 $\pm 15 \mathrm{Ma} ; 2 \sigma)$ and ${ }^{40} \mathrm{Ar} /{ }^{39} \mathrm{Ar}(280 \pm 4 \mathrm{Ma}$ and $283.8 \pm 2.2 \mathrm{Ma}, 2 \sigma)$ impact melt studies. Our (U-Th)/He age for Clearwater East also overlaps with previously published ${ }^{40} \mathrm{Ar} /{ }^{39} \mathrm{Ar}$ dating results, which yielded U-shaped spectra, with 'maximum' and 'best-estimate' dates of $\sim 460-470$ Ma. Our results support the contention, previously based solely on ${ }^{40} \mathrm{Ar} /{ }^{39} \mathrm{Ar}$ data, that the Clearwater West and East impact structures do not comprise an impact doublet that formed coevally from a binary asteroid pair. 


\section{Introduction}

Impact crater doublets have been observed on the Moon, Venus, and Mars (Bottke and Melosh, 1996), and impacts of binary asteroids are widely accepted as the most plausible formation mechanism for crater doublets (e.g., Bottke and Melosh, 1996). Binary asteroids consist of two bodies that orbit one another and share a common center-of-mass (Melosh and Stansberry, 1991), and they may comprise $\sim 15-16 \%$ of the Near Earth Asteroid (NEA) population. Six potential crater doublets have been proposed on Earth (Melosh and Stansberry, 1991; Miljković et al., 2013). One of these terrestrial impact doublets, the adjacent Clearwater East and West impact craters in Quebec, Canada (Fig. 1), have long been thought to have formed by coeval impacts at $280-290$ Ma (Dence et al., 1965; Palme et al., 1978; Reimold et al., 1981; Melosh and Stansberry, 1991; Miljković et al., 2013). However, geochronological data from the eastern crater imply that its age is much older ( 460-470 Ma; Bottomley et al., 1990; Schmieder et al., 2015) than that of the western crater ( 270-310 Ma; Wanless et al., 1965; Reimold et al., 1981; Bottomley et al., 1990; Schmieder et al., 2015). In an effort to further explore the two competing models, we obtained (U-Th)/He thermochronologic data from zircons found in impactites associated with the two craters.

Although the (U-Th)/He technique is not yet as widely applied to dating impact structures as the U-Pb, $\mathrm{Rb}-\mathrm{Sr}, \mathrm{K}-\mathrm{Ar}$, or ${ }^{40} \mathrm{Ar} /{ }^{39} \mathrm{Ar}$ methods, it is proving to be a viable technique, both when neoblastic U-Th phases like zircon form from impact melts and, especially, when impact heating was sufficiently limited so that the resetting of higher-temperature chronometers was incomplete (e.g., van Soest et al., 2011; Wartho et al., 2012).

The $(\mathrm{U}-\mathrm{Th}) / \mathrm{He}$ isotope system was the first dating method to be used as a geochronometer in the early 1900s. It is based on the decay of ${ }^{238} \mathrm{U},{ }^{235} \mathrm{U},{ }^{232} \mathrm{Th},{ }^{147} \mathrm{Sm}$ (and 
49 their intermediate daughter isotopes) to ${ }^{4} \mathrm{He}$. Early results associated with this geochronometer 50 were perceived as "nonsensical", due to ${ }^{4} \mathrm{He}$ daughter concentrations reflecting both production 51 and diffusive loss, but these initial drawbacks were later understood to be scientifically tractable 52 when the method was used as a thermochronometer that could determine low-temperature 53 thermal histories recorded in Earth's upper crust (Farley, 2002 and references therein). The primary analytical issue affecting the reliability of (U-Th)/He dates is $\alpha$-ejection, 55 which occurs when radiogenic $\alpha$-particles $\left({ }^{4} \mathrm{He}\right.$ nuclei) are propelled out of the crystal structure 56 due to the energy released by decay (Farley et al., 1996; Hourigan et al., 2005). This causes the 57 outermost margins of the crystal to be depleted in ${ }^{4} \mathrm{He}$ and may result in anomalously young 58 dates. Methods for calculating and applying $\alpha$-ejection corrections can result in accurate ages 59 with total $2 \sigma$ analytical errors typically in the range of $6-10 \%$, but sometimes larger errors (up to $6030 \%$ ) are obtained (Hourigan et al., 2005). Properly corrected (U-Th)/He ages are consistent with 61 results obtained using other geochronological systems (e.g., U-Pb and ${ }^{40} \mathrm{Ar} /{ }^{39} \mathrm{Ar}$ ) on rapidly 62 cooled samples (e.g., Farley, 2002). (U-Th)/He dating has been successfully deployed on a wide 63 variety of minerals (e.g., zircon, apatite, monazite, titanite, garnet, magnetite, hematite, and 64 merrillite) over a wide range of ages (e.g., ka to Ga; Min et al., 2013 and references therein). 65 This thermochronological method offers a reliable and powerful tool for constraining the thermal 66 histories of the upper crust of the Earth and Mars (e.g., Farley, 2002; Min et al., 2013), as well as 67 the shock metamorphism history of meteorites (e.g., Min et al., 2013 and references therein). 68 Here we apply the technique to date a renowned pair of impact craters on Earth. 


\section{Geologic background}

The $\sim 32 \mathrm{~km}$ diameter Clearwater West impact structure is located approximately $110 \mathrm{~km}$ east of Hudson Bay (56 $\left.13^{\prime} \mathrm{N} ; 7^{\circ} 30^{\prime} \mathrm{W}\right)$ in northern Quebec, Canada, where it lies adjacent to the smaller $\sim 26 \mathrm{~km}$ diameter Clearwater East impact structure $\left(56^{\circ} 05^{\prime} \mathrm{N}\right.$ and $\left.74^{\circ} 07^{\prime} \mathrm{W}\right)$. Approximately $30 \mathrm{~km}$ separates the centers of the two craters (Fig. 1, Dence et al., 1977; Bottke and Melosh, 1996). The Clearwater East and West structures are now fully and partially submerged, respectively, by Clearwater Lake/Lac à l'Eau Claire.

The Clearwater East and West structures were first linked to probable meteorite impacts by Beals et al. (1956), and their impact origin was later confirmed by petrographic, geochemical and structural studies (McIntyre, 1962; Dence et al., 1965; Grieve, 1978; Simonds et al., 1978). Both structures are classified as complex craters with central uplifts (Dence et al., 1977; Grieve, 1978; Simonds et al., 1978).

The target rocks for both impact structures are predominantly late Archean $(\sim 2694-2711$ Ma) granitic gneisses, and metamorphosed granodiorite, diorite, and tonalite, with subordinate occurrences of more mafic lithologies, all belonging to the Superior Province of the Canadian Shield (Rosa and Martin, 2010 and references therein). Metamorphic assemblages in these Archean rocks indicate amphibolite to granulite facies conditions. Various down-faulted blocks of limestone reflect the impact-induced disruption of the Ordovician ( 485-443 Ma) sedimentary cover at Clearwater West (Reimold et al., 1981; Rosa and Martin, 2010). Rock outcrops in the Clearwater West crater are primarily limited to the prominent $16-20 \mathrm{~km}$ diameter island ring and the central cluster of four small islands where basement rocks are exposed, while the Clearwater East structure is almost completely submerged. 
Three distinct impact-related rock types are observed on the central ring of islands of

93 Clearwater West. The basal unit is a $20 \mathrm{~m}$ thick red, friable impact-melt-bearing breccia

94

95

96

97

98

99

100

101

102

103

104

105

106

107

108

109

110

111

112

113

114

consisting of moderately shocked (12-15 GPa) Archean basement, overlain by an 18 m-thick red, well-jointed, fine-grained, clast-rich impact melt unit, and an 85 m-thick coarser-grained, poorlyjointed, clast-poor impact melt sheet (Reimold et al., 1981; Rosa and Martin, 2010). Overall, the melt rocks exposed on the islands have a minimum combined thickness of $\sim 120 \mathrm{~m}$ (Simonds et al., 1978). Much of what is known about both structures comes from the study of numerous drill cores obtained by the Dominion Observatory of Canada (Ottawa) during the early 1960s. Impactites known from Clearwater East (drill hole 2-63) include an impact breccia enclosed in a crystalline melt matrix that grades from a dark-green fine-grained layer starting at $\sim 245 \mathrm{~m}$ depth, into a gray-colored highly-vesicular coarser-grained section, before transitioning into a darker, non-vesicular coarse-grained phase where drilling was stopped at a depth of $\sim 300 \mathrm{~m}$ (grain size of the melt matrix at this depth suggests drilling was stopped near the middle of the breccia lens, Dence et al., 1965).

\section{Previous geochronological dating of Clearwater East and West}

The Clearwater impact craters have been dated previously using a variety of geochronological techniques (Wanless et al., 1965; Reimold et al., 1981; Bottomley et al., 1990; Schmieder et al., 2015), although most work has focused on the better-exposed Clearwater West structure. For the sake of clarity, we only refer to $\mathrm{K}-\mathrm{Ar},{ }^{40} \mathrm{Ar} /{ }^{39} \mathrm{Ar}$ and $\mathrm{Rb}-\mathrm{Sr}$ ages using the decay constants of Steiger and Jäger (1977) in the text. However, recalculated $\mathrm{K}-\mathrm{Ar},{ }^{40} \mathrm{Ar} /{ }^{39} \mathrm{Ar}$ and $\mathrm{Rb}$-Sr ages using more recent decay constants (e.g., Renne et al., 2011 and references therein; Rotenburg et al. 2012) are shown in Table 1. 


\subsection{Clearwater West}

K-Ar whole rock dating of Clearwater West impactites yielded ages of $291 \pm 30$ and 306

$118 \pm 30(2 \sigma$; Wanless et al., 1965; recalculated using the decay constants of Steiger and Jäger,

119 1977). Impact melt glasses yielded very young fission track ages of 34 Ma (Fleischer et al., 120 1969), but $\mathrm{Rb}-\mathrm{Sr}$ whole-rock analyses of impact melt rocks indicated a $266 \pm 15 \mathrm{Ma}$ age $(2 \sigma$;

121 Wooden \& Simonds, pers. comm., in Reimold et al., 1981). A ${ }^{40} \mathrm{Ar} /{ }^{39} \mathrm{Ar}$ study of a clast-bearing 122 impact melt yielded a plateau age of $280 \pm 4 \mathrm{Ma}(2 \sigma$; Bottomley et al., 1990). More recently, the 123 detailed study of Schmieder et al. (2015) obtained a combined ${ }^{40} \mathrm{Ar} /{ }^{39} \mathrm{Ar}$ impact melt age of $124283.8 \pm 2.2 \mathrm{Ma}(2 \sigma)$ for Clearwater West by integrating results from optically fresh impact melt 125 fragments.

\subsection{Clearwater East}

Reimold et al. (1981) used Rb-Sr data for whole rock and mineral separates from one 129 impact melt drill core sample (9A, obtained at a depth of $306.5 \mathrm{~m}$ ) to yield a mineral isochron 130 age of $287 \pm 26 \mathrm{Ma}(2 \sigma, \mathrm{n}=4)$. However, the other 8 whole rock impact melt samples failed to 131 yield a Rb-Sr isochron age. Bottomley et al. (1990) dated two clast-bearing impact melt core 132 samples by the ${ }^{40} \mathrm{Ar} /{ }^{39} \mathrm{Ar}$ method and obtained U-shaped age spectra, which they interpreted to 133 represent either the presence of excess ${ }^{40} \mathrm{Ar}$ or contamination from older inherited material. The 134 lowest temperature step of a step-heating experiment on sample CWE1090 produced a small 135 fraction of gas ( $1 \%$ of the total ${ }^{39} \mathrm{Ar}$ in the sample) with a date of $1075 \mathrm{Ma}$, falling to a minimum 136 apparent age of $465 \mathrm{Ma}$, before rising again to $640 \mathrm{Ma}$ in the final high-temperature step. A 137 second sample (CWE1070) displayed a much broader U-shaped age spectrum with a low- 
138 temperature step date of $\sim 590 \mathrm{Ma}$, a plateau consisting of 4 mid-temperature steps (representing $13980 \%$ of the total ${ }^{39} \mathrm{Ar}$ ) yielding dates of $\sim 460 \mathrm{Ma}$, before rising again to give final high140 temperature step date of 1150 Ma (Bottomley et al., 1990). Bottomley et al. (1990) concluded 141 that it was not possible to infer a reliable ${ }^{40} \mathrm{Ar} /{ }^{39} \mathrm{Ar}$ impact age from their Clearwater East 142 samples, but suggested a $\sim 60$ Ma maximum age for the impact structure. More recently, Schmieder et al. (2015) performed ${ }^{40} \mathrm{Ar} /{ }^{39} \mathrm{Ar}$ step heating analysis on two 144 chloritized impact melt samples, but they too, were unable to obtain statistically defined $145{ }^{40} \mathrm{Ar} /{ }^{39} \mathrm{Ar}$ plateau ages due to problems with excess ${ }^{40} \mathrm{Ar}$. Given the difficult-to-interpret dating 146 results, Schmieder et al. (2015) combined their dates with those of Bottomley et al. (1990) to 147 offer a "best-estimate" impact age range of $\sim 460-470 \mathrm{Ma}$ for Clearwater East, and used this 148 result to argue for diachroneity of the two impact structures.

\section{Samples and analytical methods}

Our Clearwater West sample material consisted of $2.5 \mathrm{~kg}$ of a dark red, fine-grained,

152 slightly altered and oxidized, clast-bearing impact melt (primarily of granodioritic to quartz153 monzonitic in composition along with lesser amounts of mafic gneiss, gabbro, and diabase; 154 Grieve, 1978) collected from Atkinson island. Our Clearwater East impact melt rock sample 155 material consisted of $\sim 1 \mathrm{~kg}$ of a black, coarse-grained impact melt rock (primarily a mixture of 156 granodiorite and quartz-monzonite; Grieve, 1978), that was obtained from drill core 2-63, at a 157 drill core depth of 335-341 m (Fig. 1). Both impact melt samples were crushed and sieved, and 158 heavy minerals were separated using standard density and magnetic techniques. A Leica MZ16 159 binocular microscope was used to select and accurately measure the dimensions of eighteen 
160 zircon grains (9 from each sample) for dating using the (U-Th)/He method (Online Supplement 161 Table 1).

Individually measured zircon crystals were loaded into $\mathrm{Nb}$ tubes for analysis. An

Australian Scientific Instruments Alphachron Mk I helium extraction line and quadrupole mass spectrometer was used for this study. ${ }^{4} \mathrm{He}$ was released from the $\mathrm{Nb}$-encapsulated zircon crystals by heating in vacuo using an infrared $(980 \mathrm{~nm})$ diode laser. The evolved gasses were purified using an NP10 getter kept at $\sim 350^{\circ} \mathrm{C}$ in the extraction line. $\mathrm{A}^{3} \mathrm{He}$ spike was added to enable $\mathrm{He}$ analysis by isotope dilution via a Balzers $Q M S 200$ quadrupole mass spectrometer.

After He extraction and measurement, the encapsulated zircon crystals were spiked with a solution of ${ }^{230} \mathrm{Th} /{ }^{235} \mathrm{U}$ in $\mathrm{HNO}_{3}$, and then dissolved in concentrated acids (a sequential step using 1:3 $\mathrm{HNO}_{3} / \mathrm{HF}$, followed by $\mathrm{HCl}$ ) using Parr digestion vessels heated to $225^{\circ} \mathrm{C}$. After a final dry down, samples were made up into a $6 \% \mathrm{HNO}_{3} / 0.8 \% \mathrm{HF}$ solution and analyzed with a Thermo Scientific $i C a p$ Qc quadrupole Inductively Coupled Plasma Mass Spectrometer (ICPMS). Both the Alphachron and iCap Qc systems used are located at the Group 18 Laboratories, at Arizona State University (ASU). The (U-Th)/He dates were calculated iteratively from blankcorrected ${ }^{4} \mathrm{He},{ }^{232} \mathrm{Th}$, and ${ }^{238} \mathrm{U}$ concentrations, and the raw calculated dates were corrected for $\alpha$ ejection based on optical dimension measurements of the crystals prior to analysis, following the protocols developed for zircon $\alpha$-ejection correction by Hourigan et al. (2005). Each (U-Th)/He dataset was evaluated with the Hampel identifier method (Pearson, 2011 and references therein) to aid in testing for the presence of statistical outliers. Additional details of the ASU (U-Th)/He analytical procedures can be found in van Soest et al. (2011).

Secondary electron (SE) and backscattered electron (BSE) imaging and energy dispersive X-ray spectrometry (EDS) were performed on eight small $(n=2)$ or broken $(n=6)$ zircons using 
183 a JEOL JXA-8530F electron Microprobe housed at the John M. Cowley Center for High 184 Resolution Electron Microscopy, ASU. These grains and grain fragments were not dated with the $185(\mathrm{U}-\mathrm{Th}) / \mathrm{He}$ method because they were too small or broken, plus the carbon coating required for $186 \mathrm{SE} / \mathrm{BSE} / \mathrm{EDS}$ analysis would cause a hydrocarbon contamination problem when measuring He 187 on the quadrupole mass spectrometer. However, their SE, BSE, and EDS characteristics are 188 considered representative of the population of (U-Th)/He dated zircons. Microprobe operating 189 conditions were $10 \mathrm{kV}$ acceleration voltage, $\sim 250 \mathrm{pA}$ beam current, and a working distance of $190 \sim 11 \mathrm{~mm}$. The EDS analyses were performed using a silicon drift diode detector (SDD). 191 Acquisition times were typically $\sim 25$ seconds and EDS analyses were ZAF matrix-corrected and 192 calibrated using an instrument-specific mineral standard database.

\section{5. (U-Th)/He results}

\subsection{Clearwater West}

Binocular microscope inspection of zircons extracted from the Clearwater West impact

197 melt rock sample revealed the presence of two distinct populations (Fig. 2). One population 198 displayed characteristics that resemble zircons inherited from rocks affected by meteorite impact 199 (Figs. 2a-e), including fairly euhedral shapes (Figs. 2a-b), with occasional rounded grain edges, 200 typically associated with metamorphic or detrital zircons (Corfu et al., 2003; Figs. 2c-e), and a 201 turbid or milky appearance (Figs. 2c-d). We term these "relict" crystals. Some of these semi202 opaque grains (Figs. 2a-b) contained an internal array of microfractures (Corfu et al., 2003). 
resulting in an abundance of crystal shards within the mineral separate, and a scarcity of complete euhedral grains. Based on our experience with similarly distinct zircons from the Manicouagan impact melt sheet (van Soest et al., 2011), we interpret the second population of zircons to be likely/probably neocrystalline (i.e., crystallized from the impact melt), rather than relic grains inherited from the target rocks.

Light microscope, SE and BSE imaging of the 8 small non-dated grains $(n=2)$ and 212 fragments $(n=6)$, all confirmed as zircon by EDS, revealed a variety of textures, and the details 213 of 4 grains/fragments are shown in Figs. 3a-f. Some grains were broken or split (most likely 214 during the crushing process), but their remaining interiors and exteriors are relatively smooth 215 with no evidence of fracturing (e.g., SEM-Z01 in Fig. 3a). One broken grain (SEM-Z02) 216 exhibited a smooth, but fractured exterior (Fig. 3b). Another grain exhibited a granular-textured 217 surface (i.e., SEM-Z03 in Fig. 3c). A fourth zircon fragment (SEM-Z04 in Figs. 3g-i) exhibited 218 an exterior similar to SEM-Z02, but it contained a micro-vesiculated interior. Previous studies 219 have reported granular surface textures on naturally shocked zircons and interpreted them as the 220 shock-induced transformation of pre-impact zircons into polycrystalline aggregates of zircon 221 crystallites in a glassy $\mathrm{ZrSiO}_{4}$ matrix, a transient phase that, after time, reverts back to zircon 222 (Wittmann et al., 2006 and references therein). The exact range of pressures associated with this 223 transition remains poorly constrained because shock experiments up to $\sim 80 \mathrm{GPa}$ have failed to 224 consistently produce similar textures (Wittmann et al., 2006). Previous workers have also 225 observed the presence of microvesicles in shocked zircon and have suggested that they may form 226 during degassing of a $\mathrm{ZrSiO}_{4}$ melt, at or near the melting point of zircon (i.e., $\sim 1680^{\circ} \mathrm{C}$, 227 Wittmann et al., 2006). However, the impact melt temperature at the Clearwater West crater 228 appears to be insufficiently consistent to melt and assimilate all of the observed relic zircons. 
A total of nine zircon grains were selected for analysis, five from the first inherited/relict population, and four from the second neocrystalline population. The $\mathrm{Th} / \mathrm{U}$ ratios of the individual grains support the existence of the two populations that were observed optically. $\mathrm{Th} / \mathrm{U}$ ratios for the four neocrystalline crystals range from $3.87 \pm 0.08$ to $4.82 \pm 0.90(2 \sigma)$, whereas the $\mathrm{Th} / \mathrm{U}$ ratios of the five inherited/relict crystals are lower and show a range of $0.38 \pm 0.01$ to $1.25 \pm 0.08$ $(2 \sigma)$. These $\mathrm{Th} / \mathrm{U}$ ratio ranges are distinctive given that the $2 \sigma$ errors are on the order of $\sim 2 \%$ (Fig. 2 and Online Supplement Table 1).

The individual zircon $(\mathrm{U}-\mathrm{Th}) / \mathrm{He}$ dates from Clearwater West range from $233.5 \pm 6.1$ to $323.8 \pm 9.5 \mathrm{Ma}(2 \sigma$, Online Supplement Table 1, Figs. 2 and 4). All nine analyses yielded an inverse variance-weighted mean age of $275.0 \pm 2.6 \mathrm{Ma}(2$ standard error $(\mathrm{SE})$; probability $(\mathrm{P})=$ 0.0), with a large Mean Square Weighted Deviation (MSWD) of 46.6. This large MSWD value implies that the data show much more dispersion than what might be expected from analytical imprecision alone (York et al., 2004). However, the distribution of dates suggests that the highest and lowest may be outliers given the substantially better clustering of the remaining analyses

243 (Fig. 4). This was confirmed by application of the Hampel identifier method (using an outlier 244 indicator value of $>4$ ) as applied to the chi-squared values for each date (Pearson, 2011 and 245 references therein). The inverse-variance weighted mean of the remaining seven analyses is $246280.3 \pm 3.0 \mathrm{Ma}(2 \mathrm{SE} ; \mathrm{P}=0.0)$, with a MSWD of 11.4 , but it still indicates substantial over247 dispersion within the dataset. A commonly used method to constrain the external uncertainties 248 associated with dating analyses, involves multiplying the calculated mean age error by the square 249 root of the MSWD (York et al., 2004), which in this case, yields an age of $280.3 \pm 10.2 \mathrm{Ma}$ 250 (2SE, $\mathrm{n}=7)$. However, the MSWD of 11.4 is still far outside the error bounds predicted by 251 Wendt and Carl (1991; for an ideal MSWD of 1.0) so we choose to apply a more conservative 
252 expanded uncertainty estimate of twice the standard deviation of the subpopulation of dates (e.g.,

253 Heckert and Filliben, 2003), with two outliers removed, to yield our preferred age of $280 \pm 27$

$254 \mathrm{Ma}(2 \sigma, \mathrm{n}=7)$, which we interpret as the $(\mathrm{U}-\mathrm{Th}) /$ He zircon age of the Clearwater West impact 255 structure (Fig. 4).

We also determined the $(\mathrm{U}-\mathrm{Th} / \mathrm{He})$ inverse variance-weighted mean and expanded $2 \sigma$

257 error ages of the two relic and neocrystalline zircon populations yielding values of $298 \pm 30 \mathrm{Ma}$

$258(\mathrm{MSWD}=11.1, \mathrm{n}=5)$ and $259 \pm 40 \mathrm{Ma}(\mathrm{MSWD}=35.2, \mathrm{n}=4)$, respectively, which overlap

259 within $2 \sigma$ errors. As the MSWD values of these two populations of zircons was either similar to, 260 or much higher than, the MSWD (i.e., 11.4) of the combined zircon dataset, and owing to the 261 small number of zircon grains analyzed, we prefer to use the combined dataset to determine the $262(\mathrm{U}-\mathrm{Th}) / \mathrm{He}$ age of the Clearwater West impact structure. One plausible explanation for the relict 263 grain mean age being so much older than the likely neocrystalline group could be the incomplete 264 degassing of the relict grains despite their residence time within the impact melt sheet.

\subsection{Clearwater East}

The nine zircon grains selected from the Clearwater East (CWE) drill core sample revealed moderate variability in crystal size, habit, and clarity (Fig. 5). The majority of the grains

269 showed significant rounding of the crystal edges (Figs. 5a-h) suggesting that they may be relict metamorphic grains (Corfu et al., 2003). One grain appears opaque, which may suggest it was

271 shock-metamorphosed (Fig. 5h), and one grain is clear and euhedral, which may indicate a 272 neocrystalline nature (Fig. 5i). However, most of the zircon grains contained few features that 273 could be clearly identified as impact related (Corfu et al., 2003). (U-Th)/He analyses of nine 274 single zircon crystals from Clearwater East yielded dates ranging from $132.1 \pm 4.0$ to $490 \pm 14$ 
275 Ma (2б, Online Supplement Table 1, Figs. 4-5). The Hampel identifier method, applied as

276 above, suggests that the youngest $132.1 \pm 4.0$ Ma date is a clear outlier (Fig. 4), and the inverse

277 variance-weighted mean age of the eight remaining dates is $447.1 \pm 4.6 \mathrm{Ma}(2 \mathrm{SE} ; P=0.0)$ with a

278 MSWD of 18.3. Expanding the uncertainty by multiplying the weighted mean by the square root 279 of the MSWD, yields an age of $447.1 \pm 19.8 \mathrm{Ma}$ (2SE, $n=8$; York et al., 2004), but again the 280 large MSWD indicates over-dispersion, therefore we applied an expanded uncertainty estimate 281 of twice the standard deviation of the subpopulation of dates (e.g., Heckert and Filliben, 2003), 282 with one outlier removed, to yield our preferred (U-Th)/He zircon age of $450 \pm 56 \mathrm{Ma}(2 \sigma)$ for 283 the Clearwater East impact crater (Fig. 4).

\section{Discussion}

\subsection{Robustness of the (U-Th)/He dating technique}

Having applied the (U-Th)/He dating technique to the Clearwater doublet, and compared our results to previous geochronological studies, we now assess its robustness. Analytical uncertainties associated with the individual Clearwater East and West (U-Th)/He zircon dates (2.6-3.9\% at $2 \sigma$, Online Supplement Table 1) and with our mean ages (9.6\% for Clearwater West and $12.4 \%$ for Clearwater East) are comparable to the results of many published (U-Th)/He

292 dating studies (e.g., Hourigan et al., 2005). However, our datasets are overdispersed with regards 293 to their analytical uncertainties and causes for this overdispersion could be related to a non294 uniform disturbance of the (U-Th)/He zircon system (e.g., due to locally variable degrees of 295 shock metamorphism that affected the individual zircon grains, causing differential resetting), 296 variations in He diffusion kinetics related to radiation damage that might affect resetting 
297 susceptibility during impact, post-impact He loss, or chemical zoning that might invalidate the 298 basic assumption of U-Th homogeneity used for the $\alpha$-ejection corrections.

There is no evidence for major re-heating events since the time of impacts in the 300 Clearwater Lake region (e.g., Ciesielski, 1991), although it is possible that a portion of 301 Clearwater East may have experienced a transient thermal pulse during the formation of 302 Clearwater West. Minor Mesozoic thermal perturbations of the Clearwater East and West impact 303 melt samples are not impossible via kimberlitic intrusive activity documented to the west, south, 304 and southeast of Clearwater (Zurevinski et al., 2011 and references therein). However, these 305 kimberlite locations are situated $\sim 600$ to $1200 \mathrm{~km}$ away from the Clearwater structures, so 306 thermal effects associated with them are unlikely to have had an effect on the (U-Th)/He zircon 307 systematics. To show this, we will discuss our (U-Th)/He zircon data using a theoretical minor 308 heating event to demonstrate that there is little evidence to support post-impact ${ }^{4} \mathrm{He}$ loss in the 309 zircons.

310 Partial radiogenic ${ }^{4} \mathrm{He}$ loss due to a later heating event (e.g., post-impact burial or thermal 311 effects of a nearby igneous intrusion etc.) would preferentially affect 1) smaller zircon crystals 312 (Farley, 2002 and references therein), 2) crystals with greater amounts of radiation damage 313 (Guenthner et al., 2013 and references therein) and 3) shock-induced damage (Schmieder et al., 314 2015, and references therein), much more than larger crystals and/or those with lesser radiation 315 damage. However, a plot of the average zircon crystal half-widths versus individual (U-Th)/He 316 dates (Fig. 6a) does not provide evidence for a relationship of increasing (U-Th)/He dates with 317 crystal size for either of these two impact craters. For Clearwater West, it actually shows the 318 exact opposite (Fig. 6a). 
The effects of radiation damage on He diffusion in zircon crystals are complex, with

320 Guenthner et al. (2013) showing that He diffusion is greatly enhanced in zircons that have

321 experienced high (i.e., $>2 \times 10^{18} \alpha / \mathrm{g}$ ) alpha particle doses, compared to $\alpha$ particle doses in the

322 lower range of $5 \times 10^{16}$ to $2 \times 10^{18} \alpha / \mathrm{g}$. The significant increase in He diffusion with higher $\alpha$

323 particle doses is linked to increasing amounts of structural metamictization within the zircon

324 crystal lattice. For example, the $\mathrm{He}$ closure temperature for metamict zircons is $<100^{\circ} \mathrm{C}$

325 (Guenther et al., 2013), whereas the He closure temperature of normal (non-metamict) zircons is

326 much higher at $180^{\circ} \mathrm{C}$ (Reiners et al., 2004, for grain radii of $60 \mu \mathrm{m}$, using a spherical diffusion

327 geometry, and a cooling rate of $\left.10^{\circ} \mathrm{C} / \mathrm{Ma}\right)$.

We chose a common approach, to plot eU versus (U-Th)/He date, to evaluate the 329 potential of radiation damage effects on our comparatively old zircons (grains that are assumed to have undergone the same thermal history). eU is the effective uranium concentration in a 331 zircon, which is a measure of the combined $\alpha$ particle production from the ${ }^{235} \mathrm{U},{ }^{238} \mathrm{U}$ and ${ }^{232} \mathrm{Th}$ 332 parent isotopes in the crystal (Flowers et al., 2007), and is often used as a proxy for $\alpha$ particle 333 radiation damage. Fig. $6 \mathrm{~b}$ shows eU concentrations vs. (U-Th)/He dates from the Clearwater East and West impact craters. There is a slight negative correlation (trend slope of -0.14) observed in our Clearwater East results, suggesting that radiation damage may have reduced the $\mathrm{He}$ 336 retentivity in some of our analyzed zircons (Fig. 6b). In contrast, the data plotted for the 337 Clearwater West relict and neocrystalline populations show little to no correlation (e.g., trend 338 slopes of -0.04 and 0.01 , respectively) between $\mathrm{eU}$ and (U-Th)/He dates. While eU - age 339 relationships are often used to evaluate the effects of helium diffusion changes related to 340 radiation damage of the crystal lattice, it does not actually represent a real measure of how much radiation damage is retained in a particular crystal. Another way to evaluate He diffusion kinetics 
342 in zircons is to calculate $\alpha$ particle doses that grains may retain, using their $\mathrm{U}-\mathrm{Th} / \mathrm{He}$ ages as a 343 proxy for their radiation damage retention age (following arguments presented in Guenthner et 344 al., 2013).

$\alpha$ particle doses of individual analyzed zircons were calculated using their eU values and our determined Clearwater East and West impact ages ( 450 and $\sim 280 \mathrm{Ma}$, respectively), to

347 further evaluate the potential of radiation damage effects on our results. The calculations yield $\alpha$ 348 particle doses ranging from $9.6 \times 10^{17}$ to $1.9 \times 10^{18} \alpha / g$ for the neocrystalline zircon population 349 from Clearwater West, $5.7 \times 10^{16}$ to $4.7 \times 10^{17} \alpha / \mathrm{g}$ for the relict population from Clearwater 350 West, and $4.1 \times 10^{17}$ to $1.1 \times 10^{18} \alpha / \mathrm{g}$ for the relict zircons from Clearwater East (Fig. 6c). These 351 calculated values are all lower than the $\sim 2 \times 10^{18} \alpha / \mathrm{g}$ alpha particle dose suggested by Guenthner 352 et al. (2013) as the lower cutoff value for enhanced He diffusion in metamict zircons, and 353 therefore suggest that minor post-impact heating events are unlikely to have been the cause for 354 the dispersion observed in our $(\mathrm{U}-\mathrm{Th}) / \mathrm{He}$ zircon data.

The above scenario assumes that the impact events that reset the He systematics of the crystals also annealed the radiation damage these crystals had retained (following the arguments 357 by Guenthner et al. (2013) that alpha particle damage anneals at the same or close to the same 358 temperature range that He systematics are reset). However, not much is known about the actual $\alpha$ 359 radiation damage annealing kinetics so it is possible that the relict grains may retain radiation 360 damage from their history prior to the impact. To calculate the maximum $\alpha$ particle doses that the 361 relict zircon crystal populations in both craters may have received, we assumed that their pre362 impact formation ages are $2.7 \mathrm{Ga}$ based on 2.4-3.1 Ga ages quoted for basement rocks of the 363 Superior Province (e.g., Reimold et al., 1981). The calculations yield maximum $\alpha$ particle doses 364 ranging from $7.3 \times 10^{17}$ to $8.3 \times 10^{18} \alpha / g$ (Fig. 6c) for relict zircon grains in both impact craters 
365 (with the exception of one zircon crystal), all higher than the $2 \times 10^{18} \mathrm{\alpha} / \mathrm{g}$ metamict zircon dose 366 of Guenthner et al., (2013) (Fig. 6c). If the relict grains retained this much radiation damage we 367 would expect a much stronger correlation between the eU concentrations and (U-Th)/He zircon 368 dates compared with those observed in Fig. 6b, in response to a minor post-impact heating event. Based on these calculations it is unlikely that radiation damage is a major cause for the 370 age overdisperion observed in our $(\mathrm{U}-\mathrm{Th}) / \mathrm{He}$ data, and there is no evidence of post-impact 371 heating events that affected the He systematics of the zircons. It is plausible that radiation 372 damage could explain the young date of relict grain CWE Z01 (132 $\pm 4 \mathrm{Ma}, 2 \sigma$, Online 373 Supplement Table 1), but it is unclear how this one grains thermal and radiation damage histories 374 could be so different from the other grains analyzed.

375 In our opinion, the most likely cause for overdispersion is $U$ and $T h$ zoning in the 376 analyzed zircons, which can result in anomalously old and young (U-Th)/He dates. Natural 377 zircons are well documented to generally be highly zoned in U and Th (e.g., Corfu et al., 2003). 378 If a zircon grain rim is enriched in $\mathrm{U}$ and Th relative to the grain core, the (U-Th)/He $\alpha$-ejection 379 corrected date would be too young (Reiners et al., 2004; Hourigan et al., 2005). Conversely, if 380 this one grain's rim is depleted in U and Th compared to the core, the $\alpha$-ejection corrected (U$381 \mathrm{Th}$ )/He date would be too old (Hourigan et al., 2005 and references therein). Extreme cases of U 382 and Th zoning in zircons can lead to deviations from the actual (U-Th)/He age of up to $30 \%$, and 383 in some cases even higher (Hourigan et al., 2005), which easily covers the spread in helium ages 384 observed in our dataset.

Schmieder et al. (2014) questioned the validity of using the (U-Th)/He method to date 386 the formation ages of terrestrial impact structures, and suggested that the accuracy of 387 the method must be tested on well-dated, impact melt-hosted mineral specimens before it 
could be applied to the dating of impact structures with poorly constrained ages. We agree that such tests are valuable, and they have already been undertaken. For example, zircons from the crystalline impact melt of the Manicouagan impact structure in Quebec, Canada have been successfully dated by both the U-Pb technique (214 $\pm 1 \mathrm{Ma} ; 2 \sigma ;$ Hodych and Dunning, 1992) and the $(\mathrm{U}-\mathrm{Th}) / \mathrm{He}$ method $(213.2 \pm 5.4 \mathrm{Ma}, 2 \mathrm{SE}$; van Soest et al., 2011). Inevitably, the (U-Th)/He method is less precise than the U-Pb method, but studies have shown that the U-Pb systematics of relict target rock zircons are commonly not fully reset during impact crater formation events, even for very large impacts (e.g., Moser et al., 2011), and instead neocrystalline zircon grains are required for reliable $\mathrm{U}-\mathrm{Pb}$ dating of impact events (e.g., Hodych and Dunning, 1992). The ${ }^{40} \mathrm{Ar} /{ }^{39} \mathrm{Ar}$ technique offers more promise than the U-Pb method for shock metamorphism chronology, but this system is also not without issues; especially complications associated with (1) extraneous ${ }^{40} \mathrm{Ar}$ contamination as encountered by Bottomley et al. (1990) and Schmieder et al. (2015) on studies of Clearwater East, and (2) ${ }^{39} \mathrm{Ar}$ and ${ }^{37} \mathrm{Ar}$ recoil during fast neutron irradiation, resulting in complex ages (e.g., Bottomley et al., 1978). However, Schmieder et al. (2015) produced isochron plots and data tables to determine the possible influence of extraneous argon on the sampled melt rock, and to assess the validity and accuracy of their own Clearwater East results and those of Bottomley et al. (1990).

We would argue that no single geochronolgical technique can be used in all cases to successfully date impact structures. With knowledge of the availability and condition of suitable impactite material, the most accurate ages will be obtained by employing multiple geochronological techniques, especially when dealing with complex datasets from impact structures that have experienced post-impact heating and/or alteration. In addition, careful 
410 petrological, chemical and isotopic analyses can also be undertaken to fully characterize samples,

411 giving greater confidence in the quality of the ages (e.g., Mark et al., 2014).

412

413

414

6.2. Geochronological dating of Clearwater East and West impact craters and evidence of their diachronous nature

Our $280 \pm 27 \mathrm{Ma}(\mathrm{U}-\mathrm{Th}) / \mathrm{He}$ weighted mean zircon age for Clearwater West $(2 \sigma ;$ Fig. 7a) overlaps with previous K-Ar and Rb-Sr ages of $291 \pm 30$ and $306 \pm 30 \mathrm{Ma}(2 \sigma$; Wanless et al., $1965)$ and $266 \pm 15 \mathrm{Ma}(2 \sigma ;$ Wooden and Simonds, quoted in Reimold et al., 1981), respectively

418 (Fig. 7a). Our (U-Th)/He age is also statistically indistinguishable from the more precise $419{ }^{40} \mathrm{Ar} /{ }^{39} \mathrm{Ar}$ impact melt ages of $280 \pm 4 \mathrm{Ma}(2 \sigma ;$ Bottomley et al., 1990) and $283.8 \pm 2.2 \mathrm{Ma}(2 \sigma ;$ 420 Schmieder et al., 2015).

421

As Fig. $7 b$ shows, our Clearwater East (U-Th)/He age of $450 \pm 56$ Ma overlaps with both

422 the maximum $\sim 460 \mathrm{Ma}{ }^{40} \mathrm{Ar} /{ }^{39} \mathrm{Ar}$ age estimate reported by Bottomley et al. (1990), and the $423 \sim 460-470 \mathrm{Ma}{ }^{40} \mathrm{Ar} /{ }^{39} \mathrm{Ar}$ "best-estimate" age range given by Schmieder et al. (2015). The 424 Clearwater East ${ }^{40} \mathrm{Ar} /{ }^{39} \mathrm{Ar}$ age estimates and (U-Th)/He ages are not in agreement with the $\mathrm{Rb}-\mathrm{Sr}$ 425 whole-rock and mineral isochron age of $287 \pm 26 \mathrm{Ma}(2 \sigma, \mathrm{n}=4$; Reimold et al., 1981). The 426 Reimold et al. (1981) Rb-Sr isochron age was obtained from one whole rock sample and 3 427 mineral separates (sample 9A), but 8 other analyzed whole rock impact melt samples failed to 428 yield a Rb-Sr isochron age. Replotting the Reimold et al. (1981) Rb-Sr data using Isoplot v. 4.15 429 (Ludwig, 2011) yields a Rb-Sr whole rock and mineral isochron age of $287 \pm 110 \mathrm{Ma}(95 \%$ 430 confidence, initial ${ }^{87} \mathrm{Sr} /{ }^{86} \mathrm{Sr}=0.7221 \pm 0.0020, \mathrm{MSWD}=44, \mathrm{P}=0.00, \mathrm{n}=4$ ) for an Isoplot 431 Model 3 data fit, which assumes any excess scatter is the result of a uniform error in the ${ }^{87} \mathrm{Sr} /{ }^{86} \mathrm{Sr}$ 432 ratios, but also takes data point errors into consideration. This recalculated $\mathrm{Rb}-\mathrm{Sr}$ isochron age of 
$433287 \pm 110 \mathrm{Ma}(95 \%$ conf.) and its larger uncertainty, brings it within $4 \mathrm{Ma}$ of our (U-Th)/He

434 zircon age of $447 \pm 56 \mathrm{Ma}(2 \sigma)$, but it still does not quite overlap.

435 Our new $(\mathrm{U}-\mathrm{Th}) / \mathrm{He}$ geochronological results lend credence to the interpretation of 436 Schmieder et al. (2015) that the Clearwater East and West impact structures were formed by two 437 different impact events separated in time by $\sim 170 \mathrm{Ma}$, with the first projectile (forming the 438 Clearwater East impact crater) striking during the Ordovician (Figs. 4 \& 7b) and the second, later 439 impact structure event (forming Clearwater West) occurring during the Cisuralian (i.e., Early 440 Permian, Figs. 4 \& 7a). It is worth noting that the later Permian impact of Clearwater West, 441 appears to have had minimal thermal overprinting effect on both the $(\mathrm{U}-\mathrm{Th}) / \mathrm{He}$ and ${ }^{40} \mathrm{Ar} /{ }^{39} \mathrm{Ar} \mathrm{K}-$ 442 feldspar ages of Clearwater East, perhaps limiting the shock metamorphism and subsequent 443 hydrothermal temperatures in our Clearwater East samples to temperatures of $<230^{\circ} \mathrm{C}$ (i.e., a 444 calculated helium closure temperature for $100 \mu \mathrm{m}$ diameter zircon grain with a rapid $445\left(1000^{\circ} \mathrm{C} / \mathrm{Ma}\right)$ cooling rate, using the helium diffusion parameters of Reiners et al. (2004)). Our 446 Clearwater East sample was obtained from drill hole 2-63 at a depth of $\sim 340 \mathrm{~m}$, and this drill 447 hole is situated ca. $40 \mathrm{~km}$ away from the center of the $32 \mathrm{~km}$ diameter Clearwater West impact 448 crater (i.e., beyond the outer rim of the western crater). There is additional corroborating evidence in support of the diachronic nature of

450 Clearwater East and West. Firstly, the paleomagnetic study of Scott et al. (1997) showed that the 451 Clearwater West and East impact structures have recorded different natural remnant 452 magnetizations, an unexpected observation if they were formed at the same time. A second 453 important observation has been the presence of Ordovician carbonate clasts detected within 454 impact breccias sampled from the Permian Clearwater West structure, while Ordovician 455 carbonates have not been detected in drill core samples from the older Clearwater East crater 
456 (Schmieder et al., 2015 and references therein). A third inconsistency is that no meteoritic

457 signature has been detected in Clearwater West impact melt samples, while Clearwater East

458 impact melt shows a significant ( 7\%) chondritic signature (Palme et al., 1978).

459

460

\subsection{Timing of the Clearwater East and West impact events}

The Permian impact age for Clearwater West does not correlate with any well-known

extinction or bio-diversification event. However, within uncertainties, the Ordovician age of

Clearwater East overlaps with: 1) both pulses ( 445 Ma and $\sim 439 \mathrm{Ma})$ of the Ordovician-

Silurian mass extinction event (Darroch and Wagner, 2015); 2) the Great Ordovician

biodiversification event; and 3) the $470 \pm 6$ Ma breakup of the L-chondrite parent body (Fig. 8;

466 Schmitz et al., 2008 and references therein). Fig. 8 shows that a comparatively large number of

467 impact structures, mainly in Northern America and Baltoscandia, were produced on Earth during 468 the Ordovician period.

469

470

\section{Conclusions}

Our (U-Th)/He zircon ages of $280 \pm 27 \mathrm{Ma}$ for Clearwater West and $450 \pm 56 \mathrm{Ma}$ for

472 Clearwater East are here interpreted as accurate crater formation ages, supporting the hypothesis

473 that the impact ages of these structures are diachronous (Schmieder et al., 2015). The two craters

474 do not appear to be a crater doublet caused by the impact of a binary asteroid.

The results of this study demonstrate that the $(\mathrm{U}-\mathrm{Th}) / \mathrm{He}$ dating technique is a powerful

476 tool for dating terrestrial impact structures. Our study has yielded reliable and informative ages

477 from modest sample yields (9 datable zircon grains from each crater), which may offer an

478 advantage where the sample size is limited (e.g., drill core samples), there is limited sampling 
479 availability due to location remoteness, or if impact melt rocks have been eroded or are highly

480 altered, and in cases where only lithic impact breccias (i.e., impactites without an impact melt

481 portion) are available for dating.

482 The dispersion in our Clearwater East and West (U-Th)/He individual zircon dates serves

483 to remind us that impact melt samples are composed of extremely complex material that

484 incorporate: (1) existing target rocks that are shock metamorphosed and heated to varying 485 degrees, (2) neocrystallites and, in some cases (3) a component of the extraterrestrial bolide. As 486 Deutsch and Schärer (1994) pointed out, approximately 90\% of target rocks and minerals are not 487 completely reset during impact formation events, making geochronological dating of these 488 structures extremely challenging.

489 With this in mind, we suggest that future (U-Th)/He terrestrial impact dating studies 490 could benefit from the application of the ultraviolet (UV) laser ablation technique (e.g., Tripathy491 Lang et al., 2013). UV laser microprobes have very high spatial resolution (nominally 100-250 $492 \mu \mathrm{m})$ that can be used to ablate and analyze the cores of suitable U- and Th-bearing minerals. 493 This method enables the (U-Th)/He dating of many crystals that are unsuitable for conventional 494 (U-Th)/He work due to their crystal shapes and inclusions. This approach would improve the 495 amount of data that can be obtained from small impactite samples. Moreover, the method 496 eliminates the need for $\alpha$-ejection correction of the resulting $(\mathrm{U}-\mathrm{Th}) / \mathrm{He}$ dates, unlike the 497 conventional non-abraded whole grain dating technique. However, the applicability of the UV 498 laser (U-Th)/He dating method is dependent upon the availability of grains of sufficiently large 499 size $(\geq 100-150 \mathrm{~m})$, the age of the impact structure, and the $U$ and Th contents of the minerals 500 being dated. 
503

504 505

506

507

508

509

510

511

512

513

514

515

516

517

518

519

520

521

522

523

524

525

526

527

528

529

530

531
This research was funded largely by National Science Foundation grant EAR-0948143 (J.A.

Wartho, M.C. van Soest and K.V. Hodges), with supplementary funding from a NASA SSERVI grant (K.V. Hodges). We thank Henrietta Cathey (ASU) for assistance with analytical field emission scanning electron microscopy and Cameron Mercer (ASU) for the use of his ArAR Calc ${ }^{40} \mathrm{Ar} /{ }^{39} \mathrm{Ar}$ age recalculator program used to convert published $\mathrm{K}-\mathrm{Ar}$ and ${ }^{40} \mathrm{Ar} /{ }^{39} \mathrm{Ar}$ ages using different K decay constants and age standard data. Ann Therriault and Richard Grieve of the Earth Materials Collections, Natural Resources Canada, are thanked for providing the Clearwater East impact melt sample material. The Clearwater West samples were obtained from the Canadian impact crater collection, which until recently, has been maintained by the Planetary and Space Science Centre (PASSC), University of New Brunswick, through grants awarded to JGS from the Canada Foundation for Innovation and Canadian Space Agency FAST program. Planetary and Space Science Centre publication number 82. We thank An Yin for editorial handling and Martin Schmieder and Kyle Min for their thoughtful and useful reviews.

\section{References}

Beals, C.S., Ferguson, G.M., Landau, A., 1956. Canadian Scientists Report II. A search for analogies between lunar and terrestrial topography on photographs of the Canadian Shield, Part II. J. Roy. Astron. Soc. Can. 50, 203-11.

Bottke, Jr., W.F., Melosh, H.J., 1996. Binary asteroids and the formation of doublet craters. Icarus 124: 372-91.

Bottomley, R.J., York, D., Grieve, R.A.F., 1978. ${ }^{40} \mathrm{Ar}-{ }^{39} \mathrm{Ar}$ ages of Scandinavian impact structures: I Mein and Siljan. Contrib. Mineral. Petrol., 68, 79-84.

Bottomley, R.J., York, D., Grieve, R.A.F., 1990. Argon-40-Argon-39 dating of impact craters. Lun. Planet. Sci. Conf. Proc., 20, 421-31. 
Ciesielski, A., 1991. Geology of the eastern Superior Province, James Bay and Beinville subprovinces, Quebec. Geol. Surv. Can. Open File 2398.

Cohen, K.M., Finney, S.C., Gibbard, P.L., Fan, J.-X., 2013; updated 2015. The ICS International Chronostratigraphic Chart. Episodes 36, 199-204.

Corfu, F., Hanchar, J.M., Hoskin, P.W.O., Kinny, P., 2003. Atlas of zircon textures. Rev. Min. and Geochem. 53, 469-500.

Darroch, S.AF, Wagner, P.J., 2015. Response of beta diversity to pulses of Ordovician-Silurian mass extinction. Ecology 96, 532-49.

Dence, M.R., Innes, M.J.S., Beals, C.S., 1965. On the probable meteorite origin of the Clearwater Lakes, Quebec. J. Roy. Astr. Soc. Can. 59, 13.

Dence, M.R., Grieve, R.A.F., Robertson, P.B., 1977. Terrestrial impact structures-principal characteristics and energy considerations. In: Impact and Explosion Cratering: Planetary and Terrestrial Implications, eds. Roddy, D.J., Pepin, R.O. and Merrill, R.B., Pergamon Press (New York), 247-75.

Deutsch, A., Schärer, U., 1994. Dating terrestrial impact events. Meteorit. 29, 301-22.

Farley, K.A., 2002. (U-Th)/He dating: Techniques, calibrations, and applications. Rev. Mineral. Geochem. 47, 819-44.

Farley, K.A., Wolf, R.A., Silver, L.T., 1996. The effects of long alpha-stopping distances on (UTh)/He ages. Geochim. Cosmochim. Acta 60, 4223-29.

Fleischer, R.L., Viertl, J.R.M., Price, P.B., 1969. Age of the Manicouagan and Clearwater Lakes craters. Geochim. Cosmochim. Acta 33, 523-27.

Flowers, R.M., Shuster, D.L., Wernicke, B.P., Farley, K.A., 2007. Radiation damage control on apatite (U-Th)/He dates from the Grand Canyon Region, Colorado Plateau. Geology 35, 447-50.

Grieve, R.A.F., 1978. Meteoritic component and impact melt composition at the Lac À l'Eau Claire (Clearwater) impact structures, Quebec. Geochim. Cosmochim. Acta 42, 429-31.

Guenthner, W.R., Reiners, P.W., Ketcham, R.A., Nasdala, L., Giester, G., 2013. Helium diffusion in natural zircon: Radiation damage, anisotropy, and the interpretation of zircon (UTh)/He thermochronology. Am. Jour. Sci. 313, 145-98.

Heckert, N.A., Filliben, J.J., 2003. NIST Handbook 148: Dataplot Reference Manual, Volume 2: Let subcommands and library functions, National Institute of Standards and Technology Handbook Series, p. 2-66 to 2-67. 
Hodych, J.P., Dunning, G.R., 1992. Did the Manicouagan impact trigger end-of-Triassic mass extinction? Geology 20, 51-54.

Hourigan, J.K., Reiners, P.W., Brandon, M.T., 2005. U-Th zonation-dependent alpha-ejection in (U-Th)/He chronometry. Geochim. Cosmochim. Acta 69, 3349-65.

Ludwig, K.R., 2011. User's manual for Isoplot version 4.15. A geochronological toolkit for Microsoft Excel. Berkeley. Geochronol. Cent. Spec. Publ. 4, pp. 76.

Mark, D.F., Lindgren, P., Fallick, A.E., 2014. A high-precision ${ }^{40} \mathrm{Ar}{ }^{39} \mathrm{Ar}$ age for hydrated impact glass from the Dellen impact, Sweden. Geol. Soc. London, Spec. Publ. 378, 349-366.

McIntyre, D.B., 1962. Impact metamorphism at Clearwater Lake, Quebec. J. Geophys. Res. 67, 1647.

Melosh, H.J., Stansberry. J.A., 1991. Doublet craters and the tidal disruption of binary asteroids. Icarus 94, 171-79.

Miljković, K., Collins, G.S., Mannick, S., Bland, P.A., 2013. Morphology and population of binary asteroid impact craters. Earth Planet. Sci. Lett. 363, 121-32.

Min, K, Reiners, P.W., Shuster, D.L. 2013. (U-Th)/He ages of phosphates from St. Séverin LL6 chondrite. Geochim. Cosmochim. Acta 100, 282-296.

Moser, D.E., Cupelli, C.L., Barker, I.R., Flowers, R.M., Bowman, J.R., Wooden, J., Hart, J.R., 2011. New zircon shock phenomena and their use for dating and reconstruction of large impact structures revealed by electron nanobeam (EBSD, CL, EDS) and isotopic U-Pb and (U-Th)/He analysis of the Vredefort dome. Can. J. Earth Sci. 48, 117-139.

Ormö, J., Sturkell, E., Alwmark, C., Melosh, J., 2014. First known terrestrial impact of a binary asteroid from a main belt breakup event. Scientific Reports 4, 6724.

Palme, H., Janssens, M.J., Takahashi, H., Anders, E., Hertogen, J., 1978. Meteoritic material at five large impact craters. Geochim. Cosmochim. Acta 42, 313-23.

Pearson, R. K., 2011. Exploring data in engineering, the sciences, and medicine. Oxford University Press, New York.

Reimold, W.U., Grieve, R.A.F., Palme, H., 1981. Rb-Sr dating of the impact melt from East Clearwater, Quebec. Contrib. Mineral. Petrol. 76, 73-76.

Reiners, P.W, Spell, T.L., Nicolescu, S., Zanetti, K.A., 2004. Zircon (U-Th)/He thermochronometry: He diffusion and comparisons with ${ }^{40} \mathrm{Ar} /{ }^{39} \mathrm{Ar}$ dating. Geochim. Cosmochim. Acta 68, 1857-87.

Renne, P.R., Balco, G., Ludwig, K.R., Mundil, R., Min, K., 2011. Response to the comment by W.H. Schwarz et al. on "Joint determination of ${ }^{40} \mathrm{~K}$ decay constants and ${ }^{40} \mathrm{Ar} *{ }^{40} \mathrm{~K}$ for the Fish 
655

656

657

658

659

660

661

662

663

664

665

666

Canyon sanidine standard, and improved accuracy for ${ }^{40} \mathrm{Ar} /{ }^{39} \mathrm{Ar}$ geochronology" by P.R. Renne et al. (2010). Geochim. Cosmochim. Acta 75, 5097-5100.

Rosa, D.F., Martin, R.F., 2010. A spurrite-, merwinite- and srebrodolskite-bearing skarn assemblage, West Clearwater Lake impact crater, Northern Quebec. Can. Mineral. 48, 1519-32.

Rotenburg, E., Davis, D.W., Amelin, Y., Ghosh, S., Bergquist, B.A., 2012. Determination of the decay-constant of ${ }^{87} \mathrm{Rb}$ by laboratory accumulation of ${ }^{87} \mathrm{Sr}$. Geochim. Cosmochim. Acta $85,41-$ 57.

Schmieder, M., Jourdan, F., Tohver, E., Cloutis, E.A., 2014. ${ }^{40} \mathrm{Ar} /{ }^{39} \mathrm{Ar}$ age of the Lake Saint Martin impact structure (Canada) - Unchaining the late Triassic terrestrial impact craters. Earth Planet. Sci. Lett. 406, 37-48.

Schmieder, M., Schwarz, W.H., Trieloff, M., Tohver, E., Buchner, E., Hopp, J., Osinski, G.R., 2015. New ${ }^{40} \mathrm{Ar} /{ }^{39} \mathrm{Ar}$ dating of the Clearwater Lake impact structures (Québec, Canada) - Not the binary asteroid impact it seems? Geochim. Cosmochim. Acta. 148, 304-324.

Schmitz, B., Harper. D.AT., Peucker-Ehrenbrink, B., Stouge, S., Alwmark, C., Cronholm, A., Bergström, S.M., Tassinari, M., Xiaofeng, W., 2008. Asteroid breakup linked to the great Ordovician biodiversification event. Nat. Geosci. 1, 49-53.

Scott, R.G., Pilkington, M., Tanczyk, E.I., 1997. Magnetic investigations of the West Hawk, Deep Bay and Clearwater impact structures, Canada. Meteorit. Planet. Sci. 32, 293-308.

Simard, M., Parent, M., Thériault, R., David, J., Lacoste, P., Sharma, K.N.M., 2004, Géologie de la région du lac à l'Eau Claire (34B et 34C). Ministère des Ressources Naturelles du Québec, Rapport Géologique RG 2003-8.

Simonds, C.H., Phinney, W.C., McGee, P.E., Cochran, A., 1978. West Clearwater, Quebec Impact Structure. I - Field geology, structure and bulk chemistry. II - Petrology. Lun. Planet. Sci. Conf. Proc., 9, 2633-93.

Steiger, R.H., Jäger, E., 1977. Subcommission on geochronology: Convention on the use of decay constants in geo- and cosmochronology. Earth Planet. Sci. Lett. 36, 359-62.

Tripathy-Lang, A., Hodges, K.V., Monteleone, B.D. van Soest, M.C., 2013. Laser (U-Th)/He thermochronology of detrital zircons as a tool for studying surface processes in modern catchments. J. Geophys. Res. Earth Surface, 118, 1333-1341.

van Soest, M.C, Hodges, K.V., Wartho, J.-A., Biren, M.B., Monteleone, B.D., Ramezani, J., Spray, J.G., Thompson, L.M., 2011. (U-Th)/He dating of terrestrial impact structures: The Manicouagan example. Geochem. Geophys. Geosyst. 12, 1-8. 
667 Wanless, R.K., Stevens, R.D., Lachance, G.R., Rimsaite, J.Y.H., 1965. Age determinations and 668 geological studies Part 1: Isotopic ages, Report 5. Geol. Surv. Can. paper 64-17, 105-6. Ottawa: 669 Dept. of Mines and Technical Surveys.

670

671 Wartho, J-A., van Soest M.C., King D.T., Petruny, L.W., 2012. An (U-Th)/He age for the 672 shallow-marine Wetumpka impact structure, Alabama, USA. Meteorit. Planet. Sci. 47, 1243-55.

673

674 Wendt, I., Carl, C., 1991. The statistical distribution of the mean squared weighted deviation.

675 Chem. Geol. 86, 275-85.

676

677

Wittmann, A., Kenkmann, T., Schmitt, R.T., Stöffler, D., 2006. Shock-metamorphosed zircon in

678

679

680 terrestrial impact craters. Meteorit. Planet. Sci. 41, 433-54.

681

682

683

684

York, D., Evensen, N.M., Martínez, M.L., De Basabe Delgado, J., 2004. Unified equations for the slope, intercept, and standard errors of the best straight line. Am. J. Phys. 72, 367-375.

Zurevinski, S.E., Heaman, L.M., Creaser, R.A., 2011. The origin of Triassic/Jurassic kimberlite 685 groundmass perovskite. Geochem. Geophys. Geosys. 12, Q09005. 


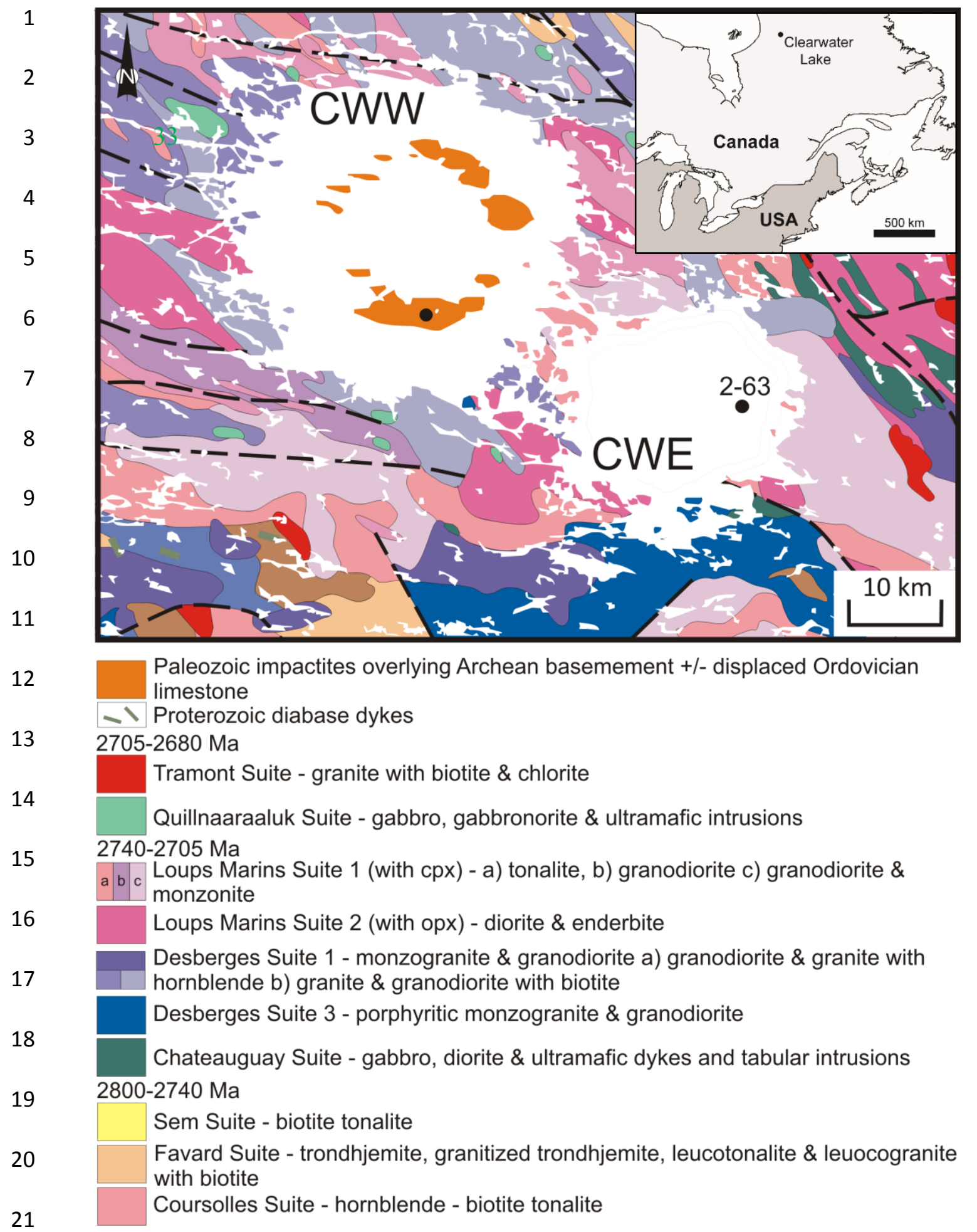

22 Fig. 1. Simplified geological map for the Clearwater West (CWW) and East (CWE) impact structures. Geology modified after Simard et al. (2004), with additional 23 compilation by L.M. Thompson. The black circles indicate impact melt sample locations from Clearwater West (Atkinson Island), and drill hole \#2-63 from Clearwater East. $\mathrm{Cpx}=$ clinopyroxene, and opx $=$ orthopyroxene. 

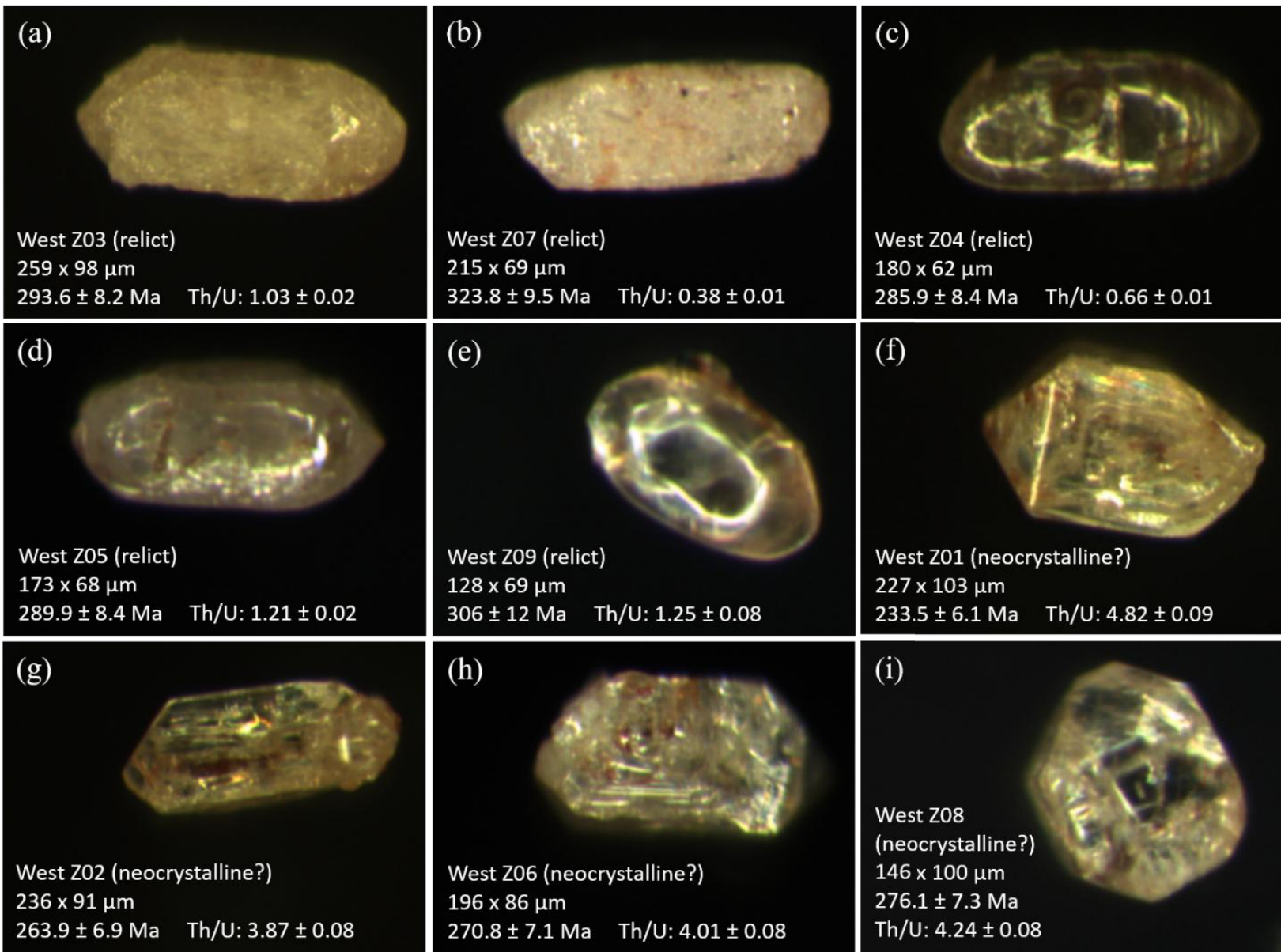

(i)

West Z08

(neocrystalline?)

$146 \times 100 \mu \mathrm{m}$

$276.1 \pm 7.3 \mathrm{Ma}$

Th/U: $4.24 \pm 0.08$

Fig. 2. Light microscope photomicrographs of Clearwater West zircon grains dated in this (UTh)/He study (with $2 \sigma$ errors), showing length and width dimensions, and $\mathrm{Th} / \mathrm{U}$ ratios (with $2 \sigma$ errors). (a) West Z03 is a slightly rounded opaque grain. (b) The oldest zircon West Z07 is opaque and subhedral. (c) West Z04 is a semi-translucent rounded grain. (d) West Z05 is a semitranslucent rounded grain. (e) West Z09 is a clear well-rounded zircon grain. (f) The youngest grain West Z01 is semi-translucent and has an asymmetric termination. (g) West Z02 is a clear euhedral crystal. (h) Zircon West Z06 shares similarities with West Z01, Z02, and Z08 including general appearance, clarity, color, habit, and $\mathrm{Th} / \mathrm{U}$ ratio. (i) Zircon West Z08 has a slight champagne-colored tint, but is relatively clear and exhibits well-defined terminations. 
47

48

49

50

51

52

53

54

55

56

57

58

59

60

61

62

63

64

65

66

67

68

69
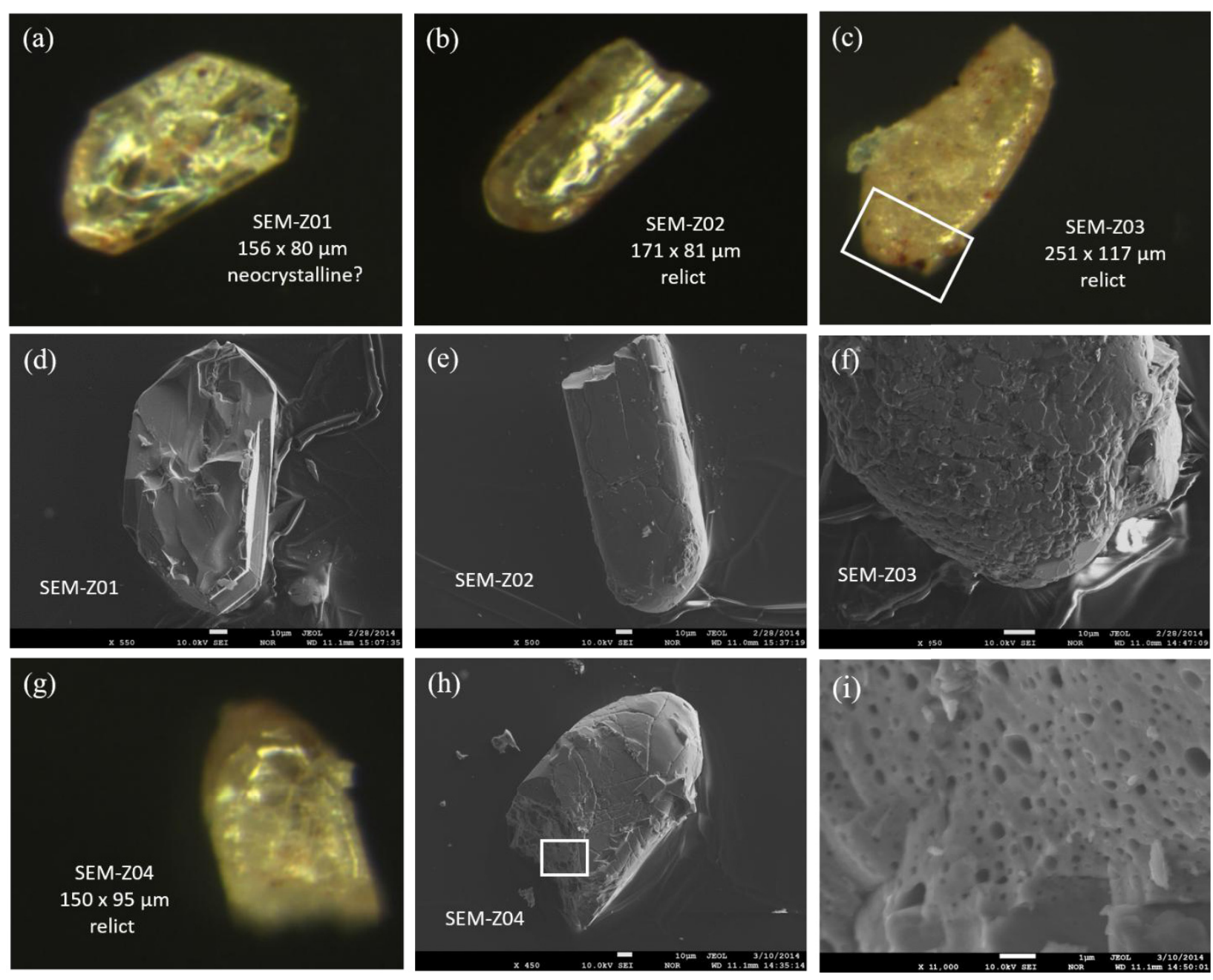

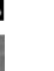


71

72

73

74

75

76

77

78

79

80

81

82

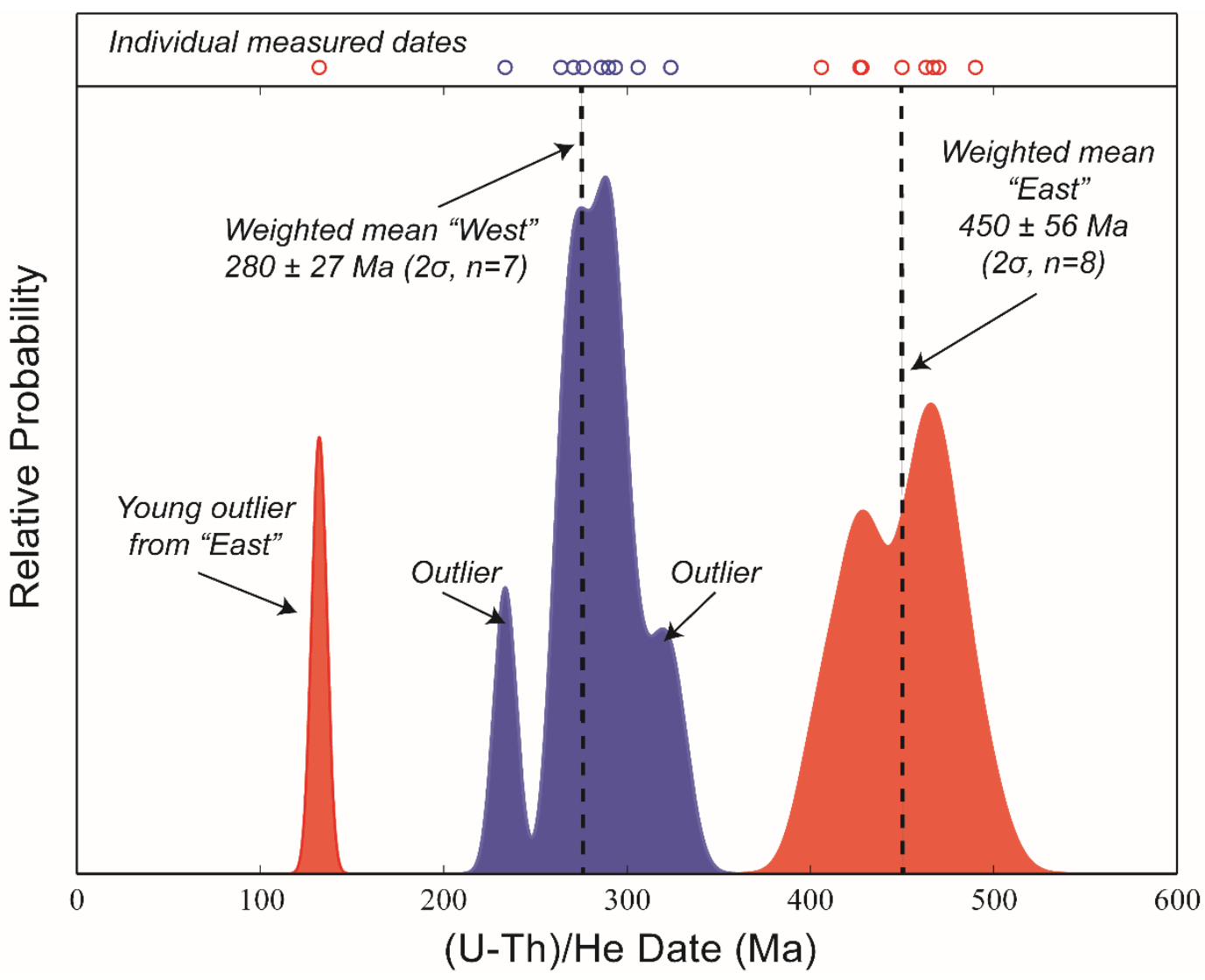

83

84 Fig. 4. Relative probability density plot of the (U-Th)/He zircon dates analyzed for the Clearwater West (blue) and Clearwater East (red) impact structures. The error-weighted (U$85 \mathrm{Th}) / \mathrm{He}$ mean age and expanded $2 \sigma$ errors for the western structure is $280 \pm 27 \mathrm{Ma}(\mathrm{n}=7$, with two outliers omitted), and the age for the eastern structure is $450 \pm 56 \mathrm{Ma}(\mathrm{n}=8$, with one outlier

86 omitted).

87

88

89

90

91

92 

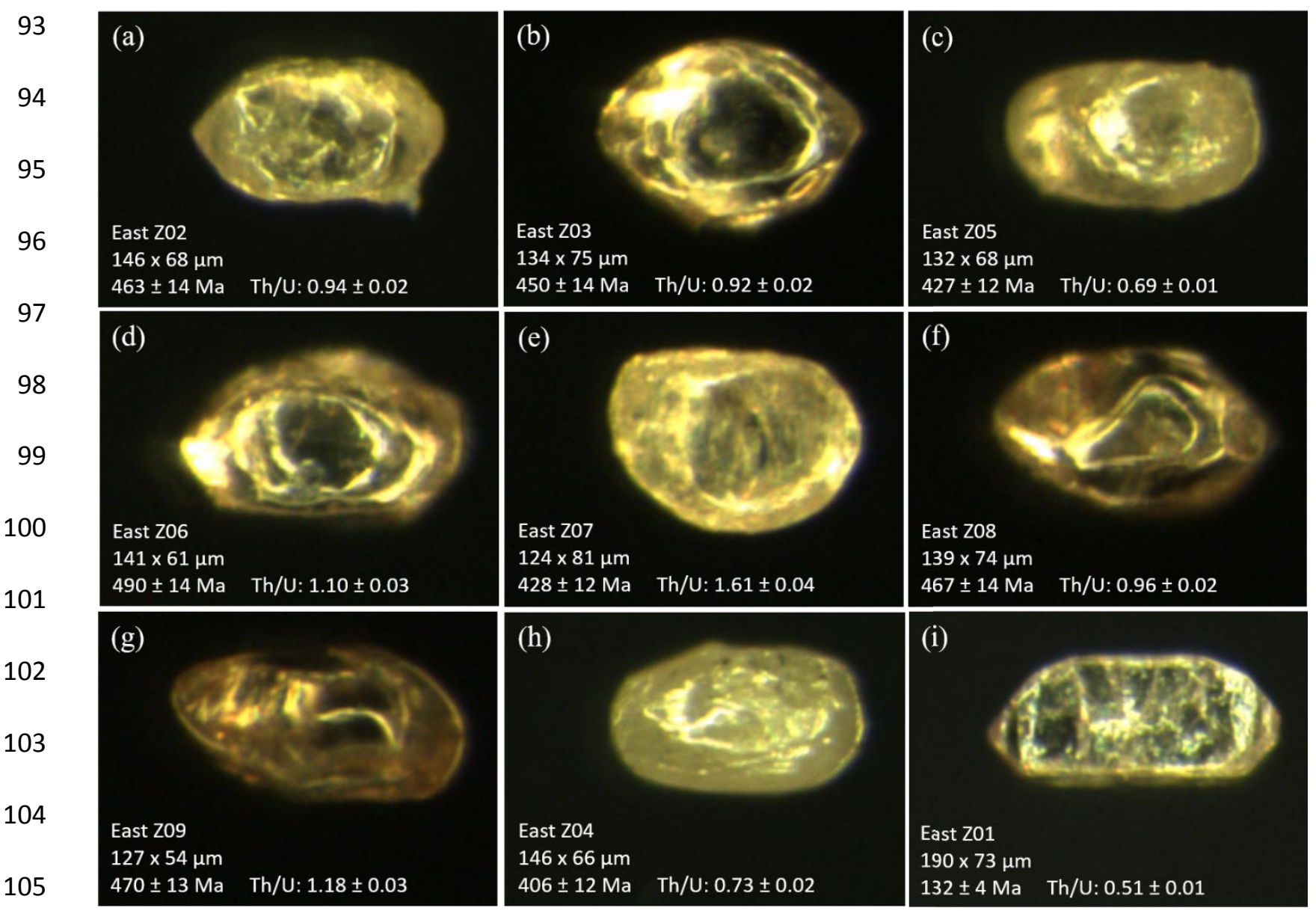

106 Fig. 5. Light microscope photomicrographs of Clearwater East zircon grains dated in this (U$\mathrm{Th}) / \mathrm{He}$ study (with $2 \sigma$ errors), showing (U-Th)/He date, length and width dimensions, and Th/U 107 ratios. (a) East Z02 is a translucent subhedral crystal. (b) East Z03 is a clear subhedral grain. (c) East Z05 is a rounded translucent grain. (d) The oldest grain East Z06 is clear and subhedral. (e) 108 East Z07 is translucent and subhedral. (f) The East Z08 zircon is subhedral and clear with a reddish tint. (g) East Z09 is a reddish, clear subhedral zircon. (h) East Z04 is opaque and 109 110 rounded, which may represent a relict grain that has been shock metamorphosed. (i) The youngest grain East Z01, is a clear euhedral zircon. 
125

126

127

128

129

130

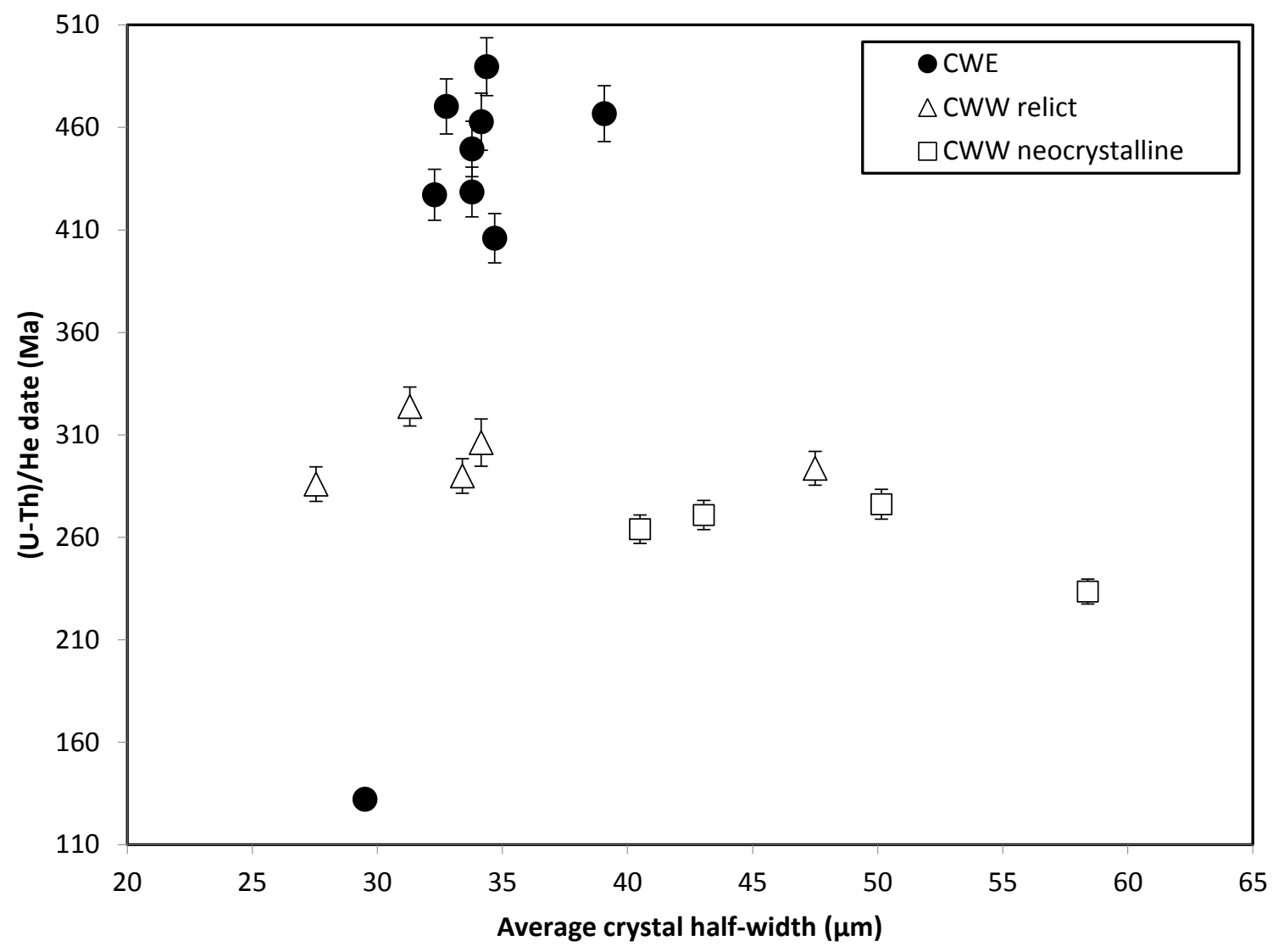

136

137

Fig. 6a. Average crystal half-width versus (U-Th)/He date ( $2 \sigma$ error bars) plot for the Clearwater West zircons (white triangles $=5$ relict grains, and white squares $=4$ neocrystalline grains), and 139 Clearwater East zircons (8 black circles).

140

141

142 
151

152

153

154

155

156

157

158

159

160

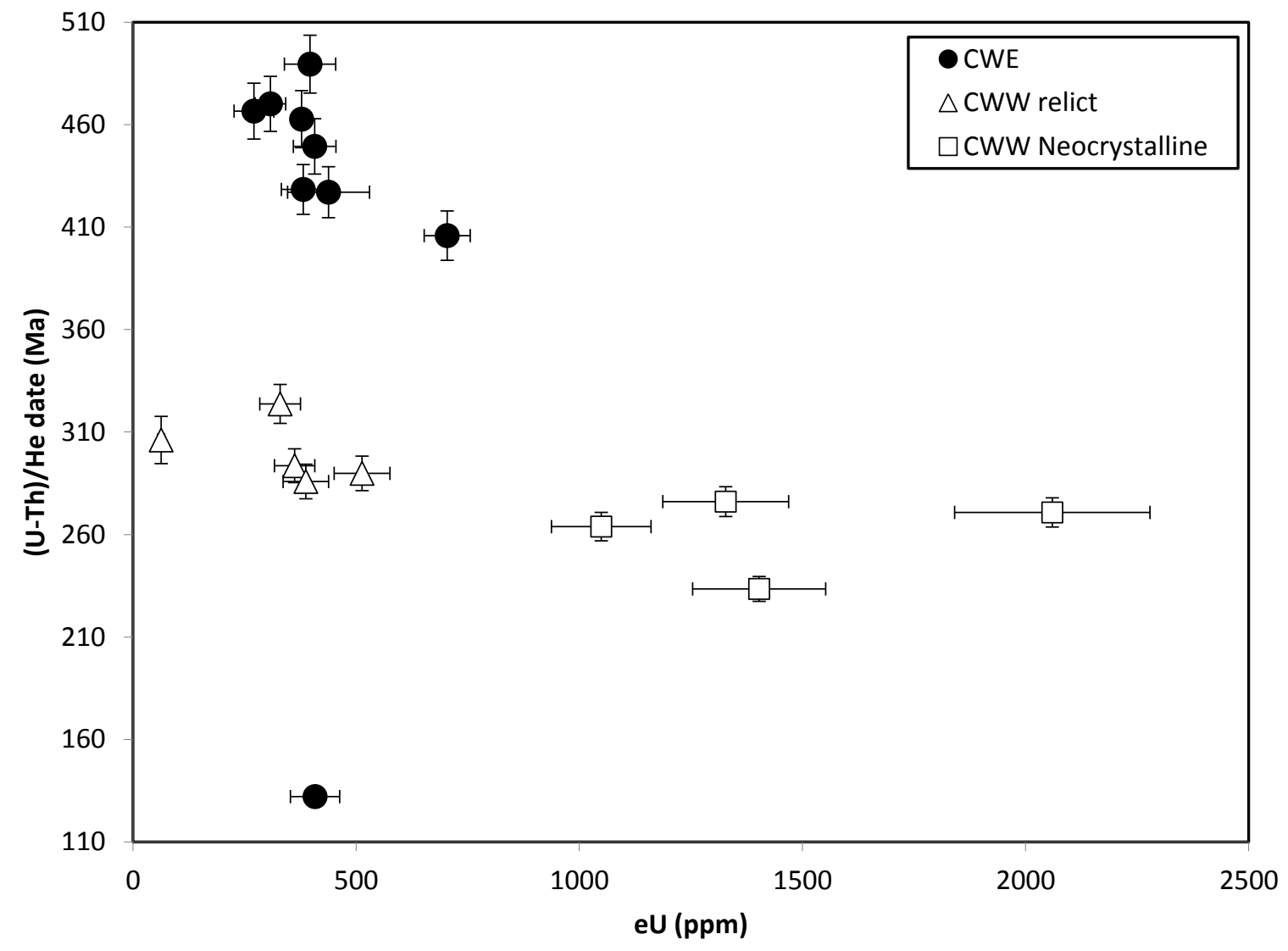

165

166

167 Fig. 6b. Effective uranium (eU) versus (U-Th)/He date $(2 \sigma$ error bars) plot for the 168 Clearwater West zircons (white triangles $=5$ relict grains, and white squares $=4$ neocrystalline grains), and Clearwater East zircons (9 black circles). 


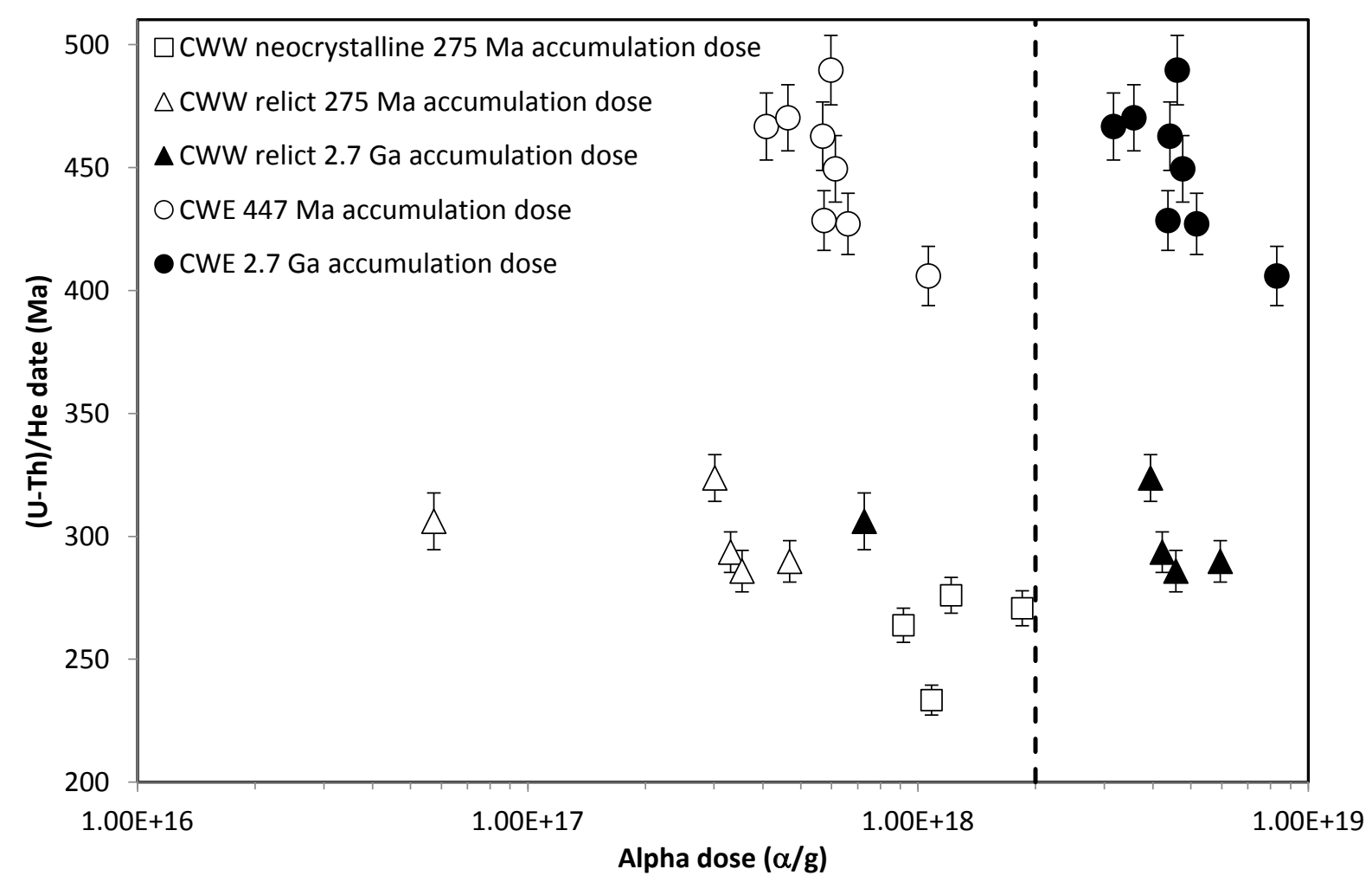

191

192 Fig. 6c. Plot of calculated alpha dose versus (U-Th)/He date $(2 \sigma$ error bars) for the Clearwater East and West zircons. The black and white triangles $=5$ relict Clearwater West grains, the black and white squares $=4$ neocrystalline Clearwater West grains, and the black and white circles $=8$ oldest Clearwater East zircons. Two different periods of accumulation were used in calculating the $\alpha$ doses for CWE (447 Ma and 2.7 Ga) and CWW (275 Ma and $2.7 \mathrm{Ga}$ ) relict grains. The dotted vertical line indicates the $>2 \times 10^{18}$ $\alpha / \mathrm{g}$ alpha particle dose of Guenthner et al. (2013), where we would expect enhanced He diffusive loss and lower He closure temperatures in the resulting metamict zircons. 


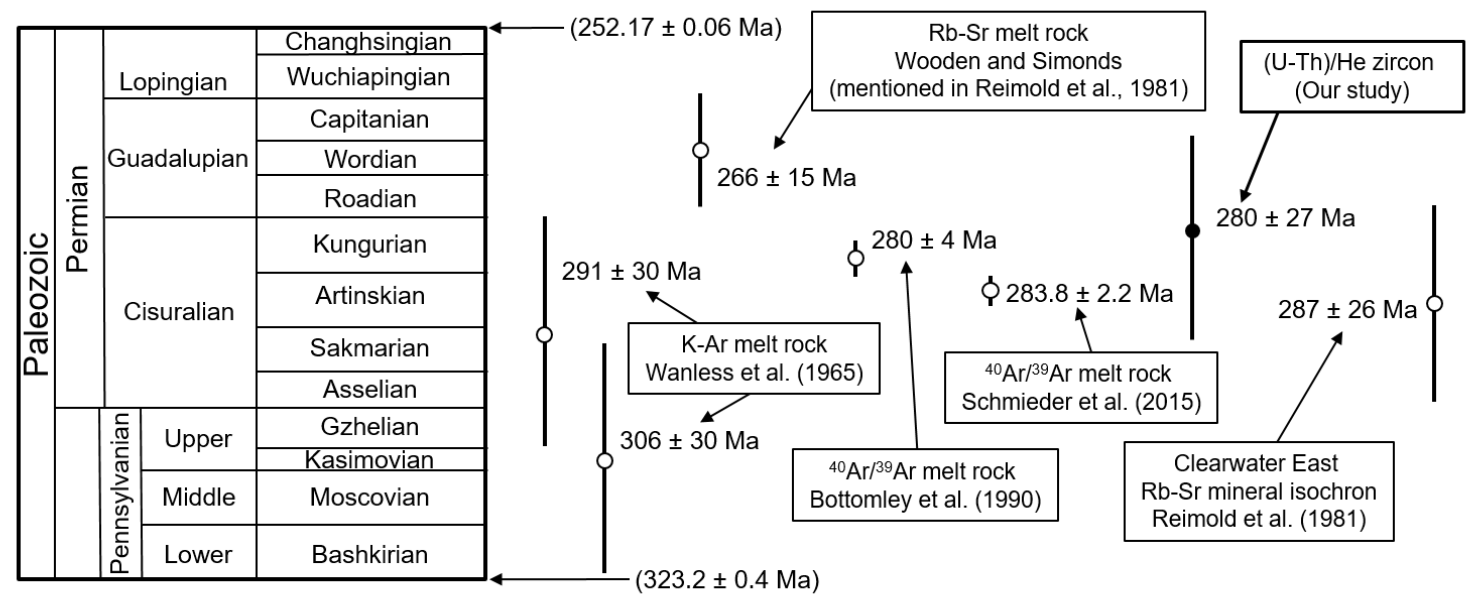

Fig. 7a. Comparison of our Clearwater West (U-Th)/He zircon age (black circle) with previous ages (white circles) published for both the Clearwater West and East (Reimold et al., 1981) impact structures, Quebec. The stratigraphic boundary ages (shown in parentheses) are taken from the International Chronostratigraphic Chart (Cohen et al., 2015). Note that the ages of Wanless et al., (1965); i.e., 285 and $300 \pm 30 \mathrm{Ma}$, and Schmieder et al. (2015; $286.2 \pm 2.2 \mathrm{Ma})$ 214 have been recalculated using the decay constants of Steiger and Jäger (1977). 

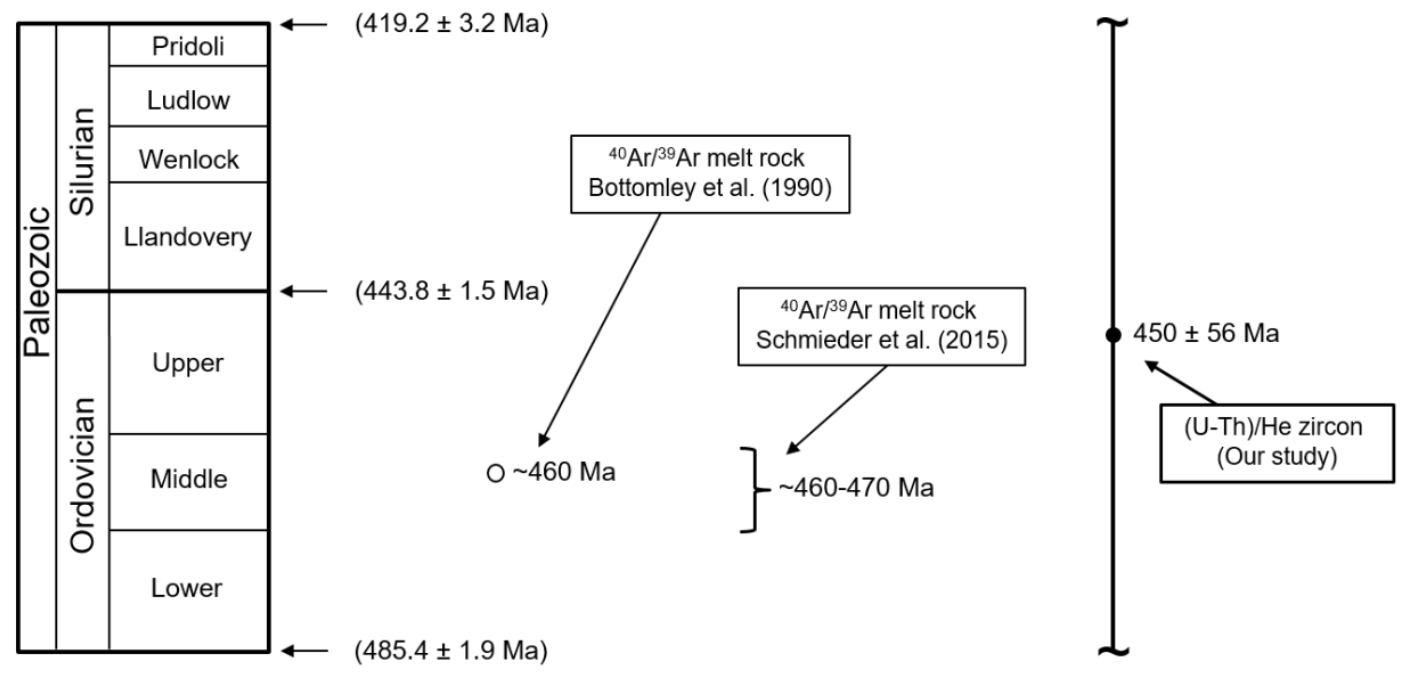

235

Fig. 7b. Comparison of our Clearwater East (U-Th)/He zircon age (black circle with truncated error bars at upper and lower limits), with the previously determined Clearwater East ${ }^{40} \mathrm{Ar} /{ }^{39} \mathrm{Ar}$ maximum age of Bottomley et al. (1990) and the "bestestimate" ${ }^{40} \mathrm{Ar} /{ }^{39} \mathrm{Ar}$ age range of Schmieder et al. (2015). The stratigraphic boundary ages (shown in parentheses) are taken from the International Chronostratigraphic Chart (Cohen et al., 2015). See Figure 7a for the previously determined Rb-Sr Clearwater East age of $287 \pm 30 \mathrm{Ma}$ (Reimold et al., 1981). 
Fig. 8. Timeline comparing our Clearwater East (U-Th)/He impact age with various 257 Ordovician impacts on Earth, and the L-Chondrite parent body break-up event (figure modified from Ormö et al., 2014). 


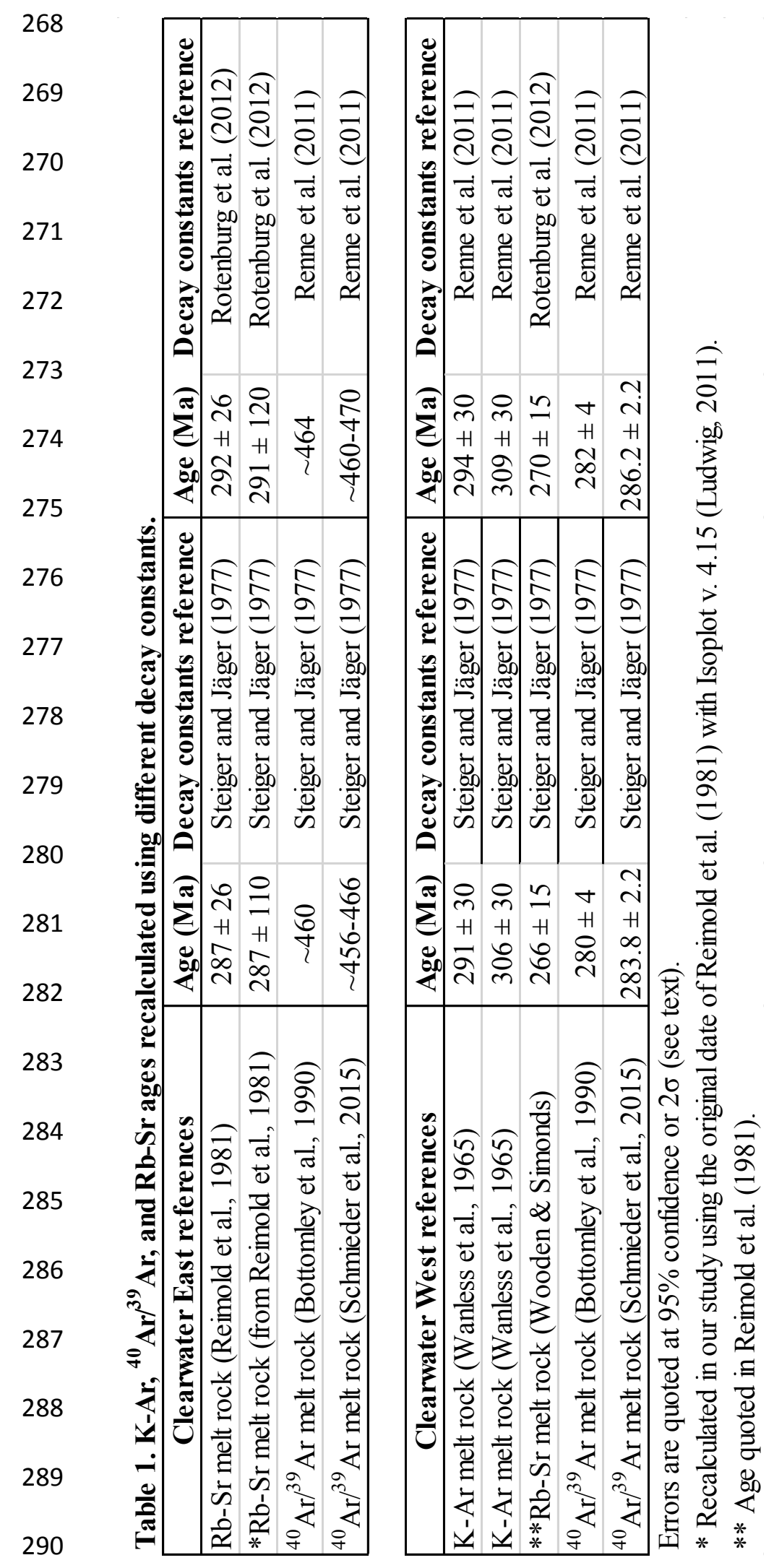




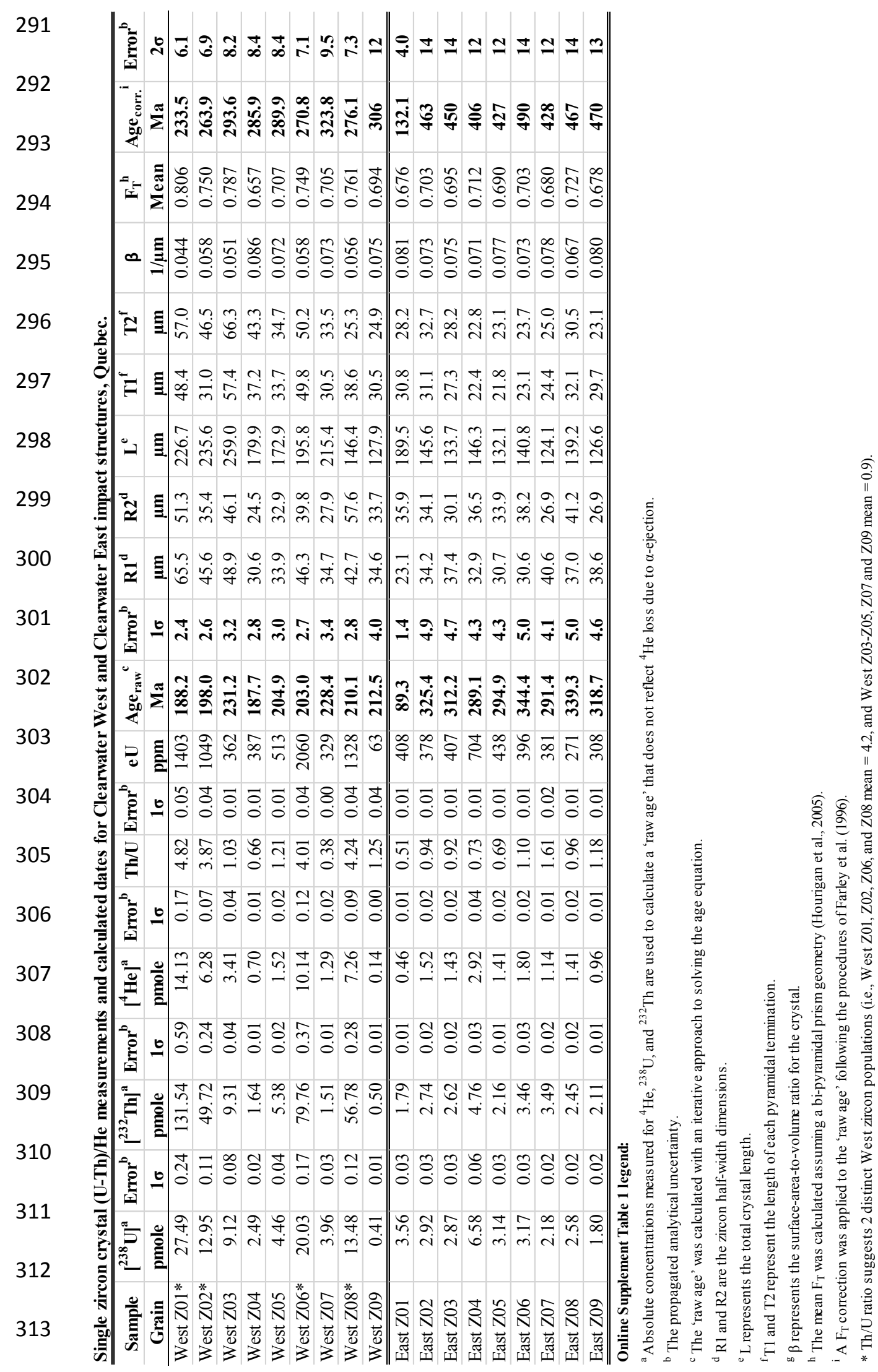

